\title{
Optimizing the Fermentation Conditions and Determining the Disease Control and Growth Promotion Function of Bacillus Amyloliquefaciens 3- 5
}

Ting Ma

Gansu Agricultural University https://orcid.org/0000-0003-3312-6753

Chengde Yang ( $\nabla$ yangcd@gsau.edu.cn )

Gansu Academy of Agricultural Sciences https://orcid.org/0000-0003-4942-8959

\section{Fengfeng Cai}

Gansu Agricultural University

Lingxiao Cui

Gansu Agricultural University

\section{Zhezhe Li}

Gansu Agricultural University

\section{Yidan Wang}

Gansu Agricultural University

\section{Research Article}

Keywords: Bacillus amyloliquefaciens 3-5, solid fermentation, optimization, growth promotion effect, control disease effect.

Posted Date: August 23rd, 2021

DOl: https://doi.org/10.21203/rs.3.rs-695841/v1

License: () (1) This work is licensed under a Creative Commons Attribution 4.0 International License. Read Full License 


\section{Abstract}

Bacillus spp. are helping to develop towards sustainable agriculture and have become a research hotspot in the field of plant pathology because they have great development potential such as control fungal plant diseases. Bacillus Amyloliquefaciens 3-5 was used as antagonistic bacteria in this experiment. The optimal medium for solid-state fermentation of $B$. amyloliquefaciens 3-5 contained bran (35\%), rice hull powder (40\%), corn gluten (20\%), bean flour (15\%), corn starch (1.5\%), beef extract $(2.5 \%)$ and $\mathrm{MgSO}_{4}(1.5 \%)$, and the optimal fermentation conditions included an inoculum of $6 \%$, a solids content of $36 \mathrm{~g} / \mathrm{L}$, a feed-to-water ratio of $1: 1$, a fermentation temperature of $32{ }^{\circ} \mathrm{C}$, an initial pH of 7.0 and fermentation time of $44 \mathrm{~h}$. When the dosage of the $B$. amyloliquefaciens 3-5 agent was $10 \%$, the thick stems, root length and plant height of cucumber were significantly higher than those of the control (P凶0.05), and the growth rates were $77.45 \%$, $35.77 \%$, and $53.33 \%$, respectively in pot experiments. Compared with the control, and the preventive effect and therapeutic effect on cucumber Fusarium wilt were $72.09 \%$ and $48.83 \%$ by the application of $B$. amyloliquefaciens 3-5 agent $₫$ which showed that cucumber Fusarium wilt was successfully controlled by a newly isolated strain of $B$. Amyloliquefaciens 3-5. These results suggested that the prevention and control effect of $B$. amyloliquefaciens 3-5 agent on cucumber Fusarium wilt could not be underestimated.

\section{Introduction}

Cucumber, a popular vegetable with young people, is an economically important crop. Vascular wilt of cucumber caused by Fusarium oxysporum f. sp. cucumerinum (FOC) is one of the most destructive soilborne diseases causing major economic losses worldwide (Qiu et al. 2012). Pathogens of the genus Fusarium have a particularly wide host range, including potato, tomato, pepper, bean, pea, chickpea, banana, strawberry, cotton, and melon, and are among the most damaging soilborne pathogens in crop production systems. They usually infect plants through the roots, and cause damping-off, root rot, and vascular wilt (Cha et al. 2016).

Chemical control with fungicides has been the most common control strategy for diseases caused by Fusarium spp. However, their extensive use has not only posed threat to pathogen resistance and the resurgence of the disease but endangered human health (Feng et al. 2021). Moreover, as a matter of common knowledge that the application of chemical fungicides leads to the selection for resistant strains, which limits their long-term efficacy (Janga et al. 2017). Furthermore, owing to the persistence or survival of F. oxysporum in the soil over long periods of time and the wide hosts range of $F$. oxysporum it is so difficult to control this disease using chemical control method (Park et al. 2020).

Therefore, safe and efficient methods for prevention and control of diseases caused by Fusarium wilt are badly needed. Biocontrol, as an eco-security, safe and sustainable method of controlling plant infections, represents a promising approach to protect crops from the pathogen (Compant et al. 2005; Haas and Keel. 2003; Hass and Défago. 2005; Lugtenberg and Kamilova. 2009). In particular biocontrol of Fusarium wilt by bacterial antagonists has been extensively studied. For example, B. subtilis SQR9 was found to control Fusarium wilt of cucumber by colonizing plant roots and producing lipopeptides (fengycin and bacillomycin) that are effective against $F$. oxysporum (Cao et al. 2011). B. velezensis RC 218 reduced 
disease severity of Fusarium head blight (FHB) caused by Fusarium graminearum and reduced accumulation of associated mycotoxins (Palazzini et al. 2016). "Amfissis" trees treated with Paenibacillus alvei K165 had significantly lower disease severity and lower relative AUDPC (Area Under the Disease Progress Curve) values than those of untreated, diseased plants (Markakis et al. 2016). Streptomyces griseorubens E44G was found to possess chitinolytic activity and was able to reduce the severity of Fusarium wilt of tomato and increase tomato growth and yield (Rashad et al. 2017). Finally, isolates of the fungus Trichoderma asperellum which had high levels of chitinase and $\beta$-1,3-glucanase activities, strongly inhibited the mycelial growth of $F$. oxysporum f. sp. lycopersici (El Komy et al. 2015). As everyone knows, microorganisms are an almost unlimited source of natural products, many of which have potential therapeutic uses. In the context of the current study, the bacterium B. amyloliquefaciens has been widely used as a probiotic in the field of biological control that its antibacterial compounds play a vital role in the prevention and control of plant, livestock and poultry diseases (Wang et al, 2020), and it has the advantages of safe, efficiency and green environmental protection.

An increasing number of literature indicated a series of advantages of endophytes. Kang et al. (2007) detailed the growth-promoting characteristics of endophytes, while Kloepper et al. (2004) and Senthilkumar et al. (2007) demonstrated the disease-inhibiting traits of endophytes. The nature of endophytes in strengthening the defence mechanism of crops to various plant diseases was researched upon by Bargabus et al. (2002), Mishra et al. (2006) and Bakker et al. (2007). In the early stage of the laboratory, endophytic strain 3-5 with magnificent antagonistic effect against Streptomyces galilaeus, the pathogen of potato scab, was screened by plate confrontation method and identified as Bacillus amyloliquefaciens. B. amyloliquefaciens 3-5 has good antagonistic effect on many pathogens such as $F$. oxysporium $\mathrm{f}$. sp. cucumerinum, F. solani, F. avenaceum, F. oxysporum f. sp. potato, F. oxysporum f. sp. melonis, F. oxysporum f. sp. chili, F. solani f. sp. chili, Alternaria solani, A. tenuissima and Colletotrichum coccodes, which showed B. amyloliquefaciens 3-5 has great application potential. It would be necessary to know "soild-state fermentation" from previous literature before the experiment started, which the level of production through solid-state fermentation depends not only on the performance of the strain itself, but on the provision of suitable fermentation conditions to fully utilize its production capacity (Kubiak et al, 2019). Research on fermentation process optimization is particularly important for its can make full use of the potential of strains,improve production efficiency and reduce production cost (Wang et al, 2018). Therefore, the solidstate fermentation conditions of $B$. amyloliquefaciens 3-5 were optimized, its antagonistic effect on FOC and other plant pathogenic fungi was determined, and its function of disease prevention and growth promotion was demonstrated in this experiment. The microbial agent was evaluated, and its growth promoting effect and disease control effect on cucumber Fusarium wilt were discussed. It not only provided the basis for the development of multifunctional $B$. amyloliquefaciens $3-5$, but also laid the foundation for the development of preventive microbial agents.

\section{Materials And Methods \\ 2.1. Test materials}




\subsubsection{The cucumber varieties}

' Xinjinyan No. 4 ', produced by Xinxiang seed industry in Henan Province, purchased from the Sandboat seed market in Anning District, Lanzhou City, Gansu Province.

\subsubsection{The antagonistic bacteria}

B. amyloliquefaciens 3-5 was isolated from commercial healthy potato tubers, and it is now stored in the laboratory of Plant Pathogenic Bacteria and Bacterial Diversity, College of Plant Protection, Gansu Agricultural University.

\subsubsection{The test medium}

Seed medium : NB medium (beef peptone $3 \mathrm{~g} / \mathrm{L}$, yeast extract $3 \mathrm{~g} / \mathrm{L}$, lactose $20 \mathrm{~g} / \mathrm{L}$, sodium chloride $3 \mathrm{~g}$ / L ).

NB medium : beef peptone $3 \mathrm{~g} / \mathrm{L}$, yeast extract $3 \mathrm{~g} / \mathrm{L}$, lactose $20 \mathrm{~g} / \mathrm{L}$, sodium chloride $3 \mathrm{~g} / \mathrm{L}$, agar $18 \mathrm{~g} /$ L.

NA medium : beef extract $5 \mathrm{~g} / \mathrm{L}$, peptone $10 \mathrm{~g} / \mathrm{L}$, sodium chloride $5 \mathrm{~g} / \mathrm{L}$, agar $18 \mathrm{~g} / \mathrm{L}$.

PDA plate : potato $200 \mathrm{~g} / \mathrm{L}$, glucose $20 \mathrm{~g} / \mathrm{L}$, agar $20 \mathrm{~g} / \mathrm{L}$.

\subsubsection{The test materials and reagents}

Carrier (wheat bran, rice bran and raw corn straw ), Filler (powdered rice hulls),Matrix carbon source (corn meal, corn starch and sugar beet pulp), Matrix nitrogen source ( soybean flour and oil residue), Carbon source (sucrose, maize starch, soluble starch, lactose, maltose and glucose), Nitrogen sources (urea, $\left(\mathrm{NH}_{4}\right)_{2} \mathrm{SO}_{4}, \mathrm{KNO}_{3}, \mathrm{NH}_{4} \mathrm{Cl}$, yeast extract and beef extract ) and Inorganic salts ( $\mathrm{NaCl}, \mathrm{MgSO}_{4}, \mathrm{MnSO}_{4}, \mathrm{FeSO}_{4}$ and $\mathrm{KH}_{2} \mathrm{PO}_{4}$ ). The above raw materials are all commercially available.

\subsection{Test methods}

\subsubsection{Microorganisms growth conditions}

In this study, a functional strain B. amyloliquefaciens $3-5$ was transferred from $-20^{\circ} \mathrm{C}$ frozen stocks to NB agar plates at $28^{\circ} \mathrm{C}$ for pre-culture before being used as inoculum for solid substrate fermentations.

\subsubsection{Preparation of seed cultures}

To prepare seed cultures, $B$. amyloliquefaciens $3-5$ colonies were inoculated from fresh NB plates in 250-mL flasks containing $50 \mathrm{~mL}$ of liquid NB medium. The flasks were incubated at $28^{\circ} \mathrm{C}$ with shaking at $180 \mathrm{rpm}$ for $24 \mathrm{~h}$.

\subsubsection{Single matrix screening}

In this experiment, bran, corn stalk, rice bran, corn flour, corn starch, soybean powder, oil residue and beet pulp residue were selected as the base medium, and the seed solution was inoculated into $20 \mathrm{~g}$ substrate 
with the ratio of material to water of $1: 1$ at $10 \%(\mathrm{v} / \mathrm{m})$. The seed solution was placed in an incubator at a constant temperature of $28^{\circ} \mathrm{C}$, and after fermentation for $36 \mathrm{~h}$, it was removed and dried in an oven at $65^{\circ} \mathrm{C} .1 \mathrm{~g}$ of fermented substrates were mixed with $99 \mathrm{~mL}$ of sterilized water containing some beads in a 250-mL flask and stirred for $20 \mathrm{~min}$ at room temperature. The number of viable germs ( $\mathrm{cfu} / \mathrm{g}$ ) was then counted using the standard dilution plate counting method (Turner and Backman 1991). All experiments were repeated three times, and the optimum substrate combination and hair were selected based on the number of viable bacteria fermentation conditions.

\subsubsection{Base matrix optimization}

In the selected single substrate, wheat bran and rice husk flour were used as the main material, and corn flour and soybean powder were used as auxiliary materials. According to the mass ratio of main and auxiliary materials, four levels were determined $90 \%: 10 \%, 80 \%: 20 \%, 70 \%: 30 \%$ and $60 \%: 40 \%$ ( Table 1 ). Count the number of viable bacteria after fermentation, and finally determine the best mass ratio of basic substrate. 
Table 1

Factors and levels of orthogonal experiment $\left(\operatorname{L16}\left(4^{4}\right)\right)$

\begin{tabular}{|llllll|}
\hline No, & Combination & \multicolumn{3}{l}{ Matrix quality(g) } \\
\cline { 3 - 6 } & & Bran & Rice husk & Corn meal & Bean flour \\
\hline 1 & $\mathrm{~B}_{1} \mathrm{R}_{1} \mathrm{C}_{1} \mathrm{~B}_{1}$ & 4.5 & 4.5 & 0.5 & 0.5 \\
\hline 2 & $\mathrm{~B}_{1} \mathrm{R}_{2} \mathrm{C}_{2} \mathrm{~B}_{2}$ & 4.5 & 4 & 1 & 1 \\
\hline 3 & $\mathrm{~B}_{1} \mathrm{R}_{3} \mathrm{C}_{3} \mathrm{~B}_{3}$ & 4.5 & 3.5 & 1.5 & 1.5 \\
\hline 4 & $\mathrm{~B}_{1} \mathrm{R}_{4} \mathrm{C}_{4} \mathrm{~B}_{4}$ & 4.5 & 3 & 2 & 2 \\
\hline 5 & $\mathrm{~B}_{2} \mathrm{R}_{1} \mathrm{C}_{2} \mathrm{~B}_{3}$ & 4 & 4.5 & 1 & 1.5 \\
\hline 6 & $\mathrm{~B}_{2} \mathrm{R}_{2} \mathrm{C}_{1} \mathrm{~B}_{4}$ & 4 & 4 & 0.5 & 2 \\
\hline 7 & $\mathrm{~B}_{2} \mathrm{R}_{3} \mathrm{C}_{4} \mathrm{~B}_{1}$ & 4 & 3.5 & 2 & 0.5 \\
\hline 8 & $\mathrm{~B}_{2} \mathrm{R}_{4} \mathrm{C}_{3} \mathrm{~B}_{2}$ & 4 & 3 & 1.5 & 1 \\
\hline 9 & $\mathrm{~B}_{3} \mathrm{R}_{1} \mathrm{C}_{3} \mathrm{~B}_{4}$ & 3.5 & 4.5 & 1.5 & 2 \\
\hline 10 & $\mathrm{~B}_{3} \mathrm{R}_{2} \mathrm{C}_{4} \mathrm{~B}_{3}$ & 3.5 & 4 & 2 & 1.5 \\
\hline 11 & $\mathrm{~B}_{3} \mathrm{R}_{3} \mathrm{C}_{1} \mathrm{~B}_{2}$ & 3.5 & 3.5 & 0.5 & 1 \\
\hline 12 & $\mathrm{~B}_{3} \mathrm{R}_{4} \mathrm{C}_{2} \mathrm{~B}_{1}$ & 3.5 & 3 & 1 & 0.5 \\
\hline 13 & $\mathrm{~B}_{4} \mathrm{R}_{1} \mathrm{C}_{4} \mathrm{~B}_{2}$ & 3 & 4.5 & 2 & 1 \\
\hline 14 & $\mathrm{~B}_{4} \mathrm{R}_{2} \mathrm{C}_{3} \mathrm{~B}_{1}$ & 3 & 4 & 1.5 & 0.5 \\
\hline 15 & $\mathrm{~B}_{4} \mathrm{R}_{3} \mathrm{C}_{2} \mathrm{~B}_{4}$ & 3 & 3.5 & 1 & 2 \\
\hline 16 & $\mathrm{~B}_{4} \mathrm{R}_{4} \mathrm{C}_{1} \mathrm{~B}_{3}$ & 3 & 3 & 0.5 & 1.5 \\
\hline
\end{tabular}

\subsubsection{Carbon source optimization}

Six carbon sources ( sucrose, corn starch, soluble starch, lactose, maltose, and glucose with a mass of $1 \%$ ) were added to the optimal substrate, and fermented in a constant temperature incubator at $28^{\circ} \mathrm{C}$. After $36 \mathrm{~h}$, the number of viable cells was determined, and the other assay methods were the same as those in Sect. 2.2.3.

\subsubsection{Nitrogen optimization}

Six nitrogen sources ( urea, $\left(\mathrm{NH}_{4}\right)_{2} \mathrm{SO}_{4}, \mathrm{KNO}_{3}, \mathrm{NH}_{4} \mathrm{Cl}$, yeast extract and beef extract with $0.5 \%$ mass ) were added to the optimum substrate and fermented in a constant temperature incubator at $28^{\circ} \mathrm{C}$. After $36 \mathrm{~h}$, the 
number of viable cells was determined. Theother test methods were the same as those described in Sect. 2.2.3.

\subsubsection{Optimization of the inorganic salt}

Five inorganic salts $\left(\mathrm{NaCl}, \mathrm{MgSO}_{4}, \mathrm{MnSO}_{4}, \mathrm{FeSO}_{4}\right.$ and $\mathrm{KH}_{2} \mathrm{PO}_{4}$ with $0.05 \%$ mass ) were added to the optimum base medium, and fermented in a constant temperature incubator at $28^{\circ} \mathrm{C}$. After $36 \mathrm{~h}$, the number of viable cells was determined, and the other test methods were the same as in Sect. 2.2.3.

\subsubsection{Optimum proportion of fermentation substrate components}

Carbon sources were adjusted four levels of $1 \%, 1.5 \%, 2 \%$ and $2.5 \%$; nitrogen sources were adjusted to 4 levels of $1 \%, 1.5 \%, 2 \%$ and $2.5 \%$; inorganic salts were adjusted to four levels of $0.5 \%, 1 \%, 1.5 \%$ and $2 \%$, and then orthogonal test was performed( Table 2 ). According to the number of viable cells to determine the optimum ratio of fermentation substrate composition, and other test methods were the same as those in Sect. 2.2.3. 
Table 2

Factors and levels of orthogonal experiment $\left(\operatorname{L16}\left(4^{3}\right)\right)$

\begin{tabular}{|c|c|c|c|c|}
\hline \multirow[t]{2}{*}{ No. } & \multirow[t]{2}{*}{ Combination } & \multicolumn{3}{|c|}{ Matrix percentage(\%) } \\
\hline & & Carbon source & Nitrogen source & Inorganic salt \\
\hline 1 & $\mathrm{C}_{1} \mathrm{~N}_{1} \mathrm{M}_{1}$ & 1 & 1 & 0.5 \\
\hline 2 & $\mathrm{C}_{1} \mathrm{~N}_{2} \mathrm{M}_{2}$ & 1 & 1.5 & 1 \\
\hline 3 & $\mathrm{C}_{1} \mathrm{~N}_{3} \mathrm{M}_{3}$ & 1 & 2 & 1.5 \\
\hline 4 & $\mathrm{C}_{1} \mathrm{~N}_{4} \mathrm{M}_{4}$ & 1 & 2.5 & 2 \\
\hline 5 & $\mathrm{C}_{2} \mathrm{~N}_{1} \mathrm{M}_{2}$ & 1.5 & 1 & 1 \\
\hline 6 & $\mathrm{C}_{2} \mathrm{~N}_{2} \mathrm{M}_{1}$ & 1.5 & 1.5 & 0.5 \\
\hline 7 & $\mathrm{C}_{2} \mathrm{~N}_{3} \mathrm{M}_{4}$ & 1.5 & 2 & 2 \\
\hline 8 & $\mathrm{C}_{2} \mathrm{~N}_{4} \mathrm{M}_{3}$ & 1.5 & 2.5 & 1.5 \\
\hline 9 & $\mathrm{C}_{3} \mathrm{~N}_{1} \mathrm{M}_{3}$ & 2 & 1 & 1.5 \\
\hline 10 & $\mathrm{C}_{3} \mathrm{~N}_{2} \mathrm{M}_{4}$ & 2 & 1.5 & 2 \\
\hline 11 & $\mathrm{C}_{3} \mathrm{~N}_{3} \mathrm{M}_{1}$ & 2 & 2 & 0.5 \\
\hline 12 & $\mathrm{C}_{3} \mathrm{~N}_{4} \mathrm{M}_{2}$ & 2 & 2.5 & 1 \\
\hline 13 & $\mathrm{C}_{4} \mathrm{~N}_{1} \mathrm{M}_{4}$ & 2.5 & 1 & 2 \\
\hline 14 & $\mathrm{C}_{4} \mathrm{~N}_{2} \mathrm{M}_{3}$ & 2.5 & 1.5 & 1.5 \\
\hline 15 & $\mathrm{C}_{4} \mathrm{~N}_{3} \mathrm{M}_{2}$ & 2.5 & 2 & 1 \\
\hline 16 & $\mathrm{C}_{4} \mathrm{~N}_{4} \mathrm{M}_{1}$ & 2.5 & 2.5 & 0.5 \\
\hline
\end{tabular}

\subsubsection{Optimization of the inoculation quantity}

In the optimum medium, the seed solutions were added at $6 \%, 8 \%, 10 \%, 12 \%$ and $14 \%$ of the inoculation amount respectively, and fermented in an incubator at a constant temperature of $28^{\circ} \mathrm{C}$. After $36 \mathrm{~h}$, the number of viable cells was determined, and other test methods were the same as in Sect. 2.2.3.

\subsubsection{Optimization of solid addition}

In the optimal matrix, the seed solutions of $5 \mathrm{~g}, 7 \mathrm{~g}, 9 \mathrm{~g}, 11 \mathrm{~g}$ and $13 \mathrm{~g}$ were added as solids to a $250 \mathrm{~mL}$ triangular flask, and fermented in a constant temperature incubator at $28^{\circ} \mathrm{C}$. After $36 \mathrm{~h}$, the number of viable cells was determined. The other test methods were the same as in Sect. 2.2.3. 


\subsubsection{Material-water ratio optimization}

In the optimum medium, the seed liquid was added with the ratio of material to water of $1: 0.6,1: 0.8,1$ : $1.0,1: 1.2$ and $1: 1.4$, respectively, and fermentation was carried out in an incubator with constant temperature at $28^{\circ} \mathrm{C}$. After $36 \mathrm{~h}$, the number of viable cells was determined, theother test methods were the same as in Sect. 2.2.3.

\subsubsection{Optimization of fermentation temperature}

Five temperature levels were set for the optimum substrate at $24^{\circ} \mathrm{C}, 28^{\circ} \mathrm{C}, 32^{\circ} \mathrm{C}, 36^{\circ} \mathrm{C}$ and $40^{\circ} \mathrm{C}$, respectively. After $36 \mathrm{~h}$, the number of viable bacteria was determined, theother test methods were the same as in Sect. 2.2.3.

The above four factors were orthogonally designed as shown in Table 3. 
Table 3

Factors and levels of orthogonal experiment $\left(\operatorname{L25}\left(4^{4}\right)\right)$

\begin{tabular}{|c|c|c|c|c|c|}
\hline \multirow[t]{2}{*}{ No. } & \multirow[t]{2}{*}{ Combination } & \multicolumn{4}{|c|}{ Levels of conditions } \\
\hline & & $\begin{array}{l}\text { Inoculum } \\
\text { size(\%) }\end{array}$ & $\begin{array}{l}\text { Solid } \\
\text { addition(g) }\end{array}$ & $\begin{array}{l}\text { Material water } \\
\text { ratio }\end{array}$ & $\begin{array}{l}\text { Fermentation } \\
\text { temperature }\left({ }^{\circ} \mathrm{C}\right)\end{array}$ \\
\hline 1 & $\mathrm{I}_{1} \mathrm{~S}_{1} \mathrm{M}_{1} \mathrm{~F}_{1}$ & 6 & 5 & 1: 0.6 & 24 \\
\hline 2 & $\mathrm{I}_{1} \mathrm{~S}_{2} \mathrm{M}_{2} \mathrm{~F}_{2}$ & 6 & 7 & 1: 0.8 & 28 \\
\hline 3 & $\mathrm{I}_{1} \mathrm{~S}_{3} \mathrm{M}_{3} \mathrm{~F}_{3}$ & 6 & 9 & 1: 1.0 & 32 \\
\hline 4 & $\mathrm{I}_{1} \mathrm{~S}_{4} \mathrm{M}_{4} \mathrm{~F}_{4}$ & 6 & 11 & 1: 1.2 & 36 \\
\hline 5 & $\mathrm{I}_{1} \mathrm{~S}_{5} \mathrm{M}_{5} \mathrm{~F}_{5}$ & 6 & 13 & 1: 1.4 & 40 \\
\hline 6 & $\mathrm{I}_{2} \mathrm{~S}_{1} \mathrm{M}_{2} \mathrm{~F}_{3}$ & 8 & 5 & 1: 0.8 & 32 \\
\hline 7 & $\mathrm{I}_{2} \mathrm{~S}_{2} \mathrm{M}_{3} \mathrm{~F}_{4}$ & 8 & 7 & 1: 1.0 & 36 \\
\hline 8 & $\mathrm{I}_{2} \mathrm{~S}_{3} \mathrm{M}_{4} \mathrm{~F}_{5}$ & 8 & 9 & 1: 1.2 & 40 \\
\hline 9 & $\mathrm{I}_{2} \mathrm{~S}_{4} \mathrm{M}_{5} \mathrm{~F}_{1}$ & 8 & 11 & $1: 1.4$ & 24 \\
\hline 10 & $\mathrm{I}_{2} \mathrm{~S}_{5} \mathrm{M}_{1} \mathrm{~F}_{2}$ & 8 & 13 & 1: 0.6 & 28 \\
\hline 11 & $\mathrm{I}_{3} \mathrm{~S}_{1} \mathrm{M}_{3} \mathrm{~F}_{5}$ & 10 & 5 & $1: 1.0$ & 40 \\
\hline 12 & $\mathrm{I}_{3} \mathrm{~S}_{2} \mathrm{M}_{4} \mathrm{~F}_{1}$ & 10 & 7 & 1: 1.2 & 24 \\
\hline 13 & $\mathrm{I}_{3} \mathrm{~S}_{3} \mathrm{M}_{5} \mathrm{~F}_{2}$ & 10 & 9 & 1: 1.4 & 28 \\
\hline 14 & $\mathrm{I}_{3} \mathrm{~S}_{4} \mathrm{M}_{1} \mathrm{~F}_{3}$ & 10 & 11 & 1: 0.6 & 32 \\
\hline 15 & $\mathrm{I}_{3} \mathrm{~S}_{5} \mathrm{M}_{2} \mathrm{~F}_{4}$ & 10 & 13 & 1: 0.8 & 36 \\
\hline 16 & $\mathrm{I}_{4} \mathrm{~S}_{1} \mathrm{M}_{4} \mathrm{~F}_{2}$ & 12 & 5 & 1: 1.2 & 28 \\
\hline 17 & $\mathrm{I}_{4} \mathrm{~S}_{2} \mathrm{M}_{5} \mathrm{~F}_{3}$ & 12 & 7 & 1: 1.4 & 32 \\
\hline 18 & $\mathrm{I}_{4} \mathrm{~S}_{3} \mathrm{M}_{1} \mathrm{~F}_{4}$ & 12 & 9 & 1: 0.6 & 36 \\
\hline 19 & $\mathrm{I}_{4} \mathrm{~S}_{4} \mathrm{M}_{2} \mathrm{~F}_{5}$ & 12 & 11 & 1: 0.8 & 40 \\
\hline 20 & $\mathrm{I}_{4} \mathrm{~S}_{5} \mathrm{M}_{3} \mathrm{~F}_{1}$ & 12 & 13 & 1: 1.0 & 24 \\
\hline 21 & $\mathrm{I}_{5} \mathrm{~S}_{1} \mathrm{M}_{5} \mathrm{~F}_{4}$ & 14 & 5 & 1: 1.4 & 36 \\
\hline 22 & $\mathrm{I}_{5} \mathrm{~S}_{2} \mathrm{M}_{1} \mathrm{~F}_{5}$ & 14 & 7 & 1: 0.6 & 40 \\
\hline
\end{tabular}




\begin{tabular}{|c|c|c|c|c|c|}
\hline \multirow[t]{2}{*}{ No. } & \multirow[t]{2}{*}{ Combination } & \multicolumn{4}{|c|}{ Levels of conditions } \\
\hline & & $\begin{array}{l}\text { Inoculum } \\
\text { size(\%) }\end{array}$ & $\begin{array}{l}\text { Solid } \\
\text { addition(g) }\end{array}$ & $\begin{array}{l}\text { Material water } \\
\text { ratio }\end{array}$ & $\begin{array}{l}\text { Fermentation } \\
\text { temperature }\left({ }^{\circ} \mathrm{C}\right)\end{array}$ \\
\hline 23 & $\mathrm{I}_{5} \mathrm{~S}_{3} \mathrm{M}_{2} \mathrm{~F}_{1}$ & 14 & 9 & $1: 0.8$ & 24 \\
\hline 24 & $\mathrm{I}_{5} \mathrm{~S}_{4} \mathrm{M}_{3} \mathrm{~F}_{2}$ & 14 & 11 & 1: 1.0 & 28 \\
\hline 25 & $\mathrm{I}_{5} \mathrm{~S}_{5} \mathrm{M}_{4} \mathrm{~F}_{3}$ & 14 & 13 & $1: 1.2$ & 32 \\
\hline
\end{tabular}

\subsubsection{Optimization of initial $\mathrm{pH}$ of fermentation}

In the optimal medium, 13 initial fermentation $\mathrm{pH}$ values were set at 4, 4.5, 5, 5.5, 6, 6.5, 7, 7.5, 8, 8.5, 9, 9.5 and 10. After $36 \mathrm{~h}$ of fermentation, the number of viable cells was determined, the other test methods were the same as in Sect. 2.2.3.

\subsubsection{Optimization of fermentation time}

Under the conditions of optimum inoculation amount, solid loading amount, solid-liquid ratio, temperature and $\mathrm{pH}$, the fermentation time was adjusted to 8 levels of $20 \mathrm{~h}, 24 \mathrm{~h}, 28 \mathrm{~h}, 32 \mathrm{~h}, 36 \mathrm{~h}, 40 \mathrm{~h}, 44 \mathrm{~h}$ and $48 \mathrm{~h}$, and the number of viable cells was measured every $4 \mathrm{~h}$ to determine the optimum fermentation time.

\subsubsection{Determination of the growth promoting effect of $B$. amyloliquefaciens 3-5 on cucumber}

The substrate soil ( provided by Gansu Lvneng Agricultural Science and Technology Co., Ltd. ) and vermiculite were thoroughly mixed at a ratio of $1: 1(\mathrm{w} / \mathrm{w})$ after autoclaved at $121^{\circ} \mathrm{C}$ for $2 \mathrm{~h}$, and supplemented with fertilizers to which 3-5 bacteriocin was added according to the mass ratio of bacteriocin to culture medium (the mixture of substrate soil and vermiculite) of $0.25 \%, 0.5 \%, 1.0 \%, 5.0 \%$, $10.0 \%$ and $20.0 \%$. The soil $(200 \mathrm{~g})$ was distributed in plastic pots $(\Phi=12 \mathrm{~cm})$, and moisture was maintained at $90 \%$ of the maximum water-holding capacity of the soil by daily addition of sterilized water. After mixing, it was placed in a $12 \mathrm{~cm} \times 12 \mathrm{~cm}$ plastic flower pot ( $200 \mathrm{~g}$ per pot ), without $B$. amyloliquefaciens $3-5$ agent as a control. Cucumber seeds with full grains were selected for germination ( soaked at $45^{\circ} \mathrm{C}$ for 2 hours ) and planted in each pot ( four plants per pot ) after germination. When the fourth true leaf of the cucumber seedlings had grown out, thefresh weight (g), dry weight (g), stem thickness $(\mathrm{cm})$, root length $(\mathrm{cm})$ and plant height $(\mathrm{cm})$ of each plant were measured (after being killed in $105^{\circ} \mathrm{C}$ oven and dried at $70^{\circ} \mathrm{C}$ to constant weight). This experiment was repeated three times. 


\subsubsection{Determination of the control effect of $B$. amyloliquefaciens 3-5 on cucumber fusarium wilt}

Disease suppression experiments on tomato seedlings were conducted as previously reported (Asaka and Shoda 1996; Mizumoto et al. 2006). The healthy cucumber seeds with equal growth vigor were planted in a plastic flower pot ( $\Phi=12 \mathrm{~cm}$ ) containing a nutrient soil with the dosage of the microbial agent was $10.0 \%$ ( nutrient soil was mixed with vermiculite at a ratio of $1: 1$ ). When the cucumber seedlings had grown out of the fourth true leaf, the experiment was conducted.

( 1 ) Prevention experiment: The soil on the surface of the flower pot was plucked off with a sterile dissector, and the bacterial agent which constituted $10.0 \%$ of the mass of the nutrient soil in the flower pot was applied to the surrounding plants. The bacterial agent was covered with the previously plucked soil. After 3 days, the soil was inoculated and pricked $10 \mathrm{~cm}$ from the stem base of the plant, and the spore suspension of FOC with the concentration of $10^{7} \mathrm{cfu} / \mathrm{mL}$ was dipped with defatted cotton and spread evenly on the microinjury site.

( 2 ) Treatment test : $10 \mathrm{~cm}$ from the stem base of the plant, a pinprick injury was inoculated and the spore suspension of FOC with a concentration of $10^{7} \mathrm{cfu} / \mathrm{mL}$ was inoculated with defatted cotton. After 3 days, $10.0 \%$ of nutrient soil was applied around the plant in the flower pot and the soil was covered with the previously released bacterial agent.

( 3 ) Control : The spore suspension of FOC containing $10^{7} \mathrm{cfu} / \mathrm{mL}$ was used as control.

Each treatment set 10 seedlings, repeated three times. After inoculation, humidification with preservative film for 48 hours, and the incidence of cucumber wilt was studied after 15 days, and the disease index and control effect of 3-5 on cucumber wilt were calculated.

The incidence and severity of wilt were scored on a $0-5$ scale; $0=$ healthy, $1=1-3$ leaves curled and yellowed, 2 = > 3 leaves curled and deformed, 3 = chlorosis and early wilting of the plant, $4=$ necrosis and wilting of the entire plant and $5=$ dead or almost dead (Sanogo et al., 2016). Disease incidence (DI) was calculated as the percentage of infected plants to the total number of plants in each block and was assessed when disease occurred ( $>20 \%$ of leaves wilted).

$\mathrm{DI}=\sum$ ( number of diseased plants $\times$ representative grade $) /($ total number of investigated plants $\times$ highest representative grade ) $\times 100$;

Control effect $(\%)=($ control disease index-treatment disease index $) /$ control disease index $\times 100$.

\subsubsection{Statistical analysis}

Three independent experiments were performed to check the reproducibility of results. Data obtained were expressed as the mean \pm standard deviation (SD) and analyzed statistically using the computer software 
package SPSS 24.0 program. Multiple comparisons were performed on the data using the one-way ANOVA program, with 0.05 set as the threshold significance level for Duncan's test (Li et al., 2010).

\section{Results}

\subsection{Matrix optimization}

\subsubsection{Single Matrix Screening}

To explore the effect of the feeding ingredients on the fermentation, we have chosen three kinds of carriers, carbon sources and nitrogen sources respectively. As shown in the Fig. 1, in the single substrate base medium with bran as carrier, the number of viable cells of $B$. amyloliquefaciens $3-5$ was the highest, which was $31.25 \times 10^{10} \mathrm{cfu} / \mathrm{g}$, which was significantly higher than that of the carrier rice bran and corn straw. In the single substrate base medium with corn flour as carbon source, the number of viable cells was the greatest $\left(8.65 \times 10^{10} \mathrm{cfu} / \mathrm{g}\right.$ ), which was significantly higher than that of corn starch and sugar beet residue. In the single substrate medium with soybean powder as nitrogen source, the number of viable bacteria was the greatest at $4 \times 10^{10} \mathrm{cfu} / \mathrm{g}$, which was significantly higher than that of the nitrogen source oil residue. Therefore, wheat bran as carrier, corn flour as carbon source and soybean flour as nitrogen source were the best substrate combination for basic medium of $B$. amyloliquefaciens 3-5.

\subsubsection{Base matrix optimization}

Following optimization the base matrix, our results showed that at aratio of bran : rice husk powder : corn flour : soybean powder of $3.5: 4: 2: 1.5$, the number of viable cells of strain $3-5$, was the highest, was 9.97 $\times 10^{12} \mathrm{cfu} / \mathrm{g}$, which was significantly higher than that of the other composite substrate combinations, indicated that the optimum combination for solid-state fermentation of $B$. amyloliquefaciens $3-5$ were 35 $\%$ bran, $40 \%$ rice husk powder, $20 \%$ corn flour and $15 \%$ soybean powder, respectively ( Table 4 ). 
Table 4

Screening of strain 3-5 composite matrix

\begin{tabular}{|c|c|c|c|c|c|c|}
\hline \multirow[t]{2}{*}{ No. } & \multirow[t]{2}{*}{ Combination } & \multicolumn{4}{|c|}{ Matrix quality(g) } & \multirow{2}{*}{$\begin{array}{l}\text { Viable bacteria } \\
\text { counts } \\
\left(\times 10^{12} \mathrm{cfu} / \mathrm{g}\right)\end{array}$} \\
\hline & & Bran & $\begin{array}{l}\text { Rice } \\
\text { husk }\end{array}$ & $\begin{array}{l}\text { Corn } \\
\text { meal }\end{array}$ & $\begin{array}{l}\text { Bean } \\
\text { flour }\end{array}$ & \\
\hline 1 & $\mathrm{~B}_{1} \mathrm{R}_{1} \mathrm{C}_{1} \mathrm{~B}_{1}$ & 4.5 & 4.5 & 0.5 & 0.5 & 2.192 \\
\hline 2 & $\mathrm{~B}_{1} \mathrm{R}_{2} \mathrm{C}_{2} \mathrm{~B}_{2}$ & 4.5 & 4 & 1 & 1 & 2.089 \\
\hline 3 & $\mathrm{~B}_{1} \mathrm{R}_{3} \mathrm{C}_{3} \mathrm{~B}_{3}$ & 4.5 & 3.5 & 1.5 & 1.5 & 1.905 \\
\hline 4 & $\mathrm{~B}_{1} \mathrm{R}_{4} \mathrm{C}_{4} \mathrm{~B}_{4}$ & 4.5 & 3 & 2 & 2 & 1.080 \\
\hline 5 & $\mathrm{~B}_{2} \mathrm{R}_{1} \mathrm{C}_{2} \mathrm{~B}_{3}$ & 4 & 4.5 & 1 & 1.5 & 0.762 \\
\hline 6 & $\mathrm{~B}_{2} \mathrm{R}_{2} \mathrm{C}_{1} \mathrm{~B}_{4}$ & 4 & 4 & 0.5 & 2 & 1.064 \\
\hline 7 & $\mathrm{~B}_{2} \mathrm{R}_{3} \mathrm{C}_{4} \mathrm{~B}_{1}$ & 4 & 3.5 & 2 & 0.5 & 0.522 \\
\hline 8 & $\mathrm{~B}_{2} \mathrm{R}_{4} \mathrm{C}_{3} \mathrm{~B}_{2}$ & 4 & 3 & 1.5 & 1 & 1.000 \\
\hline 9 & $\mathrm{~B}_{3} \mathrm{R}_{1} \mathrm{C}_{3} \mathrm{~B}_{4}$ & 3.5 & 4.5 & 1.5 & 2 & 1.445 \\
\hline 10 & $\mathrm{~B}_{3} \mathrm{R}_{2} \mathrm{C}_{4} \mathrm{~B}_{3}$ & 3.5 & 4 & 2 & 1.5 & 9.970 \\
\hline 11 & $\mathrm{~B}_{3} \mathrm{R}_{3} \mathrm{C}_{1} \mathrm{~B}_{2}$ & 3.5 & 3.5 & 0.5 & 1 & 1.502 \\
\hline 12 & $\mathrm{~B}_{3} \mathrm{R}_{4} \mathrm{C}_{2} \mathrm{~B}_{1}$ & 3.5 & 3 & 1 & 0.5 & 1.772 \\
\hline 13 & $\mathrm{~B}_{4} \mathrm{R}_{1} \mathrm{C}_{4} \mathrm{~B}_{2}$ & 3 & 4.5 & 2 & 1 & 3.115 \\
\hline 14 & $\mathrm{~B}_{4} \mathrm{R}_{2} \mathrm{C}_{3} \mathrm{~B}_{1}$ & 3 & 4 & 1.5 & 0.5 & 0.814 \\
\hline 15 & $\mathrm{~B}_{4} \mathrm{R}_{3} \mathrm{C}_{2} \mathrm{~B}_{4}$ & 3 & 3.5 & 1 & 2 & 1.609 \\
\hline 16 & $\mathrm{~B}_{4} \mathrm{R}_{4} \mathrm{C}_{1} \mathrm{~B}_{3}$ & 3 & 3 & 0.5 & 1.5 & 0.994 \\
\hline K1 & & 5.449 & 5.635 & 4.313 & 3.974 & \\
\hline $\mathrm{K} 2$ & & 2.510 & 10.451 & 4.673 & 5.779 & \\
\hline K3 & & 11.016 & 5.420 & 3.873 & 10.110 & \\
\hline K4 & & 4.898 & 3.634 & 11.015 & 3.899 & \\
\hline
\end{tabular}

Note: $\mathrm{K} 1$ represents the average value of the four tests at the first level of each factor; $\mathrm{K} 2$ represents the second level of each factor and the mean value of the four tests; K3 represents the average value of the third level four tests of each factor; K4 represents the fourth level of each factor and the average of the four trials. 


\begin{tabular}{|c|c|c|c|c|c|c|}
\hline \multirow[t]{2}{*}{ No. } & \multirow[t]{2}{*}{ Combination } & \multicolumn{4}{|c|}{ Matrix quality(g) } & \multirow{2}{*}{$\begin{array}{l}\text { Viable bacteria } \\
\text { counts } \\
\left(\times 10^{12} \mathrm{cfu} / \mathrm{g}\right)\end{array}$} \\
\hline & & Bran & $\begin{array}{l}\text { Rice } \\
\text { husk }\end{array}$ & $\begin{array}{l}\text { Corn } \\
\text { meal }\end{array}$ & $\begin{array}{l}\text { Bean } \\
\text { flour }\end{array}$ & \\
\hline $\begin{array}{l}\text { Best } \\
\text { organization }\end{array}$ & & K3 & K2 & K4 & K3 & \\
\hline \multicolumn{7}{|c|}{$\begin{array}{l}\text { Note: } \mathrm{K} 1 \text { represents the average value of the four tests at the first level of each factor; K2 represents the } \\
\text { second level of each factor and the mean value of the four tests; K3 represents the average value of the } \\
\text { third level four tests of each factor; } K 4 \text { represents the fourth level of each factor and the average of the } \\
\text { four trials. }\end{array}$} \\
\hline
\end{tabular}

\subsection{Optimization of solid fermentation substrate \\ 3.2.1 Carbon source optimization}

For the different carbon sources that we tested, our results showed that $B$. amyloliquefaciens $3-5$ had the highest number of viable cells $\left(2.48 \times 10^{13} \mathrm{cfu} / \mathrm{g}\right)$ in the solid matrix with corn starch as carbon source which was significantly higher than that of other carbon sources (Fig. 2).

\subsubsection{Nitrogen source optimization}

The influence of different nitrogen sources on the visible counts was shown in the Fig. 3 . The visible number of the strain in the solid matrix with yeast extract as nitrogen source was $0.87 \times 10^{13} \mathrm{cfu} / \mathrm{g}$; In the solid matrix with beef extract as nitrogen source, the number of viable cells of strain 3-5 was the largest, which was $1.21 \times 10^{13} \mathrm{cfu} / \mathrm{g}$. In conclusion, the viable count of beef extract with nitrogen source was significantly higher than the visible counts of urea, $\left(\mathrm{NH}_{4}\right)_{2} \mathrm{SO}_{4}, \mathrm{KNO}_{3}, \mathrm{NH}_{4} \mathrm{Cl}$ and yeast extract with nitrogen source.

\subsubsection{Inorganic salt optimization}

The suitable inorganic salt was critical for the viable cells growth because of it is a useful ingredient in media for the cultivation microorganisms. As shown in the Fig. 4, the number of viable cells of strain 3-5 was the largest when in the solid medium with $\mathrm{MgSO}_{4}$ as inorganic salt, was $2.13 \times 10^{13} \mathrm{cfu} / \mathrm{g}$, which was significantly higher than that of $\mathrm{NaCl}, \mathrm{MnSO}_{4}, \mathrm{FeSO}_{4}$ and $\mathrm{KH}_{2} \mathrm{PO}_{4}$. 
Table 5

Screening of carbon source, nitrogen source and inorganic salt

\begin{tabular}{|c|c|c|c|c|c|}
\hline \multirow[t]{3}{*}{ No. } & \multirow[t]{3}{*}{ Combination } & & & & \multirow{3}{*}{$\begin{array}{l}\text { Viable bacteria } \\
\text { counts } \\
\left(\times 10^{13} \mathrm{cfu} / \mathrm{g}\right)\end{array}$} \\
\hline & & \multicolumn{3}{|c|}{ Matrix percentage(\%) } & \\
\hline & & $\begin{array}{l}\text { Carbon } \\
\text { source }\end{array}$ & $\begin{array}{l}\text { Nitrogen } \\
\text { source }\end{array}$ & $\begin{array}{l}\text { Inorganic } \\
\text { salt }\end{array}$ & \\
\hline 1 & $\mathrm{C}_{1} \mathrm{~N}_{1} \mathrm{M}_{1}$ & 1 & 1 & 0.5 & 0.023 \\
\hline 2 & $\mathrm{C}_{1} \mathrm{~N}_{2} \mathrm{M}_{2}$ & 1 & 1.5 & 1 & 0.146 \\
\hline 3 & $\mathrm{C}_{1} \mathrm{~N}_{3} \mathrm{M}_{3}$ & 1 & 2 & 1.5 & 0.423 \\
\hline 4 & $\mathrm{C}_{1} \mathrm{~N}_{4} \mathrm{M}_{4}$ & 1 & 2.5 & 2 & 0.247 \\
\hline 5 & $\mathrm{C}_{2} \mathrm{~N}_{1} \mathrm{M}_{2}$ & 1.5 & 1 & 1 & 2.345 \\
\hline 6 & $\mathrm{C}_{2} \mathrm{~N}_{2} \mathrm{M}_{1}$ & 1.5 & 1.5 & 0.5 & 0.955 \\
\hline 7 & $\mathrm{C}_{2} \mathrm{~N}_{3} \mathrm{M}_{4}$ & 1.5 & 2 & 2 & 1.243 \\
\hline 8 & $\mathrm{C}_{2} \mathrm{~N}_{4} \mathrm{M}_{3}$ & 1.5 & 2.5 & 1.5 & 2.415 \\
\hline 9 & $\mathrm{C}_{3} \mathrm{~N}_{1} \mathrm{M}_{3}$ & 2 & 1 & 1.5 & 0.413 \\
\hline 10 & $\mathrm{C}_{3} \mathrm{~N}_{2} \mathrm{M}_{4}$ & 2 & 1.5 & 2 & 1.538 \\
\hline 11 & $\mathrm{C}_{3} \mathrm{~N}_{3} \mathrm{M}_{1}$ & 2 & 2 & 0.5 & 1.507 \\
\hline 12 & $\mathrm{C}_{3} \mathrm{~N}_{4} \mathrm{M}_{2}$ & 2 & 2.5 & 1 & 2.407 \\
\hline 13 & $\mathrm{C}_{4} \mathrm{~N}_{1} \mathrm{M}_{4}$ & 2.5 & 1 & 2 & 0.375 \\
\hline 14 & $\mathrm{C}_{4} \mathrm{~N}_{2} \mathrm{M}_{3}$ & 2.5 & 1.5 & 1.5 & 0.317 \\
\hline 15 & $\mathrm{C}_{4} \mathrm{~N}_{3} \mathrm{M}_{2}$ & 2.5 & 2 & 1 & 0.867 \\
\hline 16 & $\mathrm{C}_{4} \mathrm{~N}_{4} \mathrm{M}_{1}$ & 2.5 & 2.5 & 0.5 & 0.483 \\
\hline K1 & & 0.210 & 0.790 & 0.740 & \\
\hline K2 & & 1.740 & 0.740 & 0.890 & \\
\hline K3 & & 1.470 & 1.010 & 1.440 & \\
\hline K4 & & 0.510 & 1.390 & 0.850 & \\
\hline
\end{tabular}

Note: $\mathrm{k} 1$ represents the average value of the four tests at the first level of each factor; $\mathrm{K} 2$ represents the second level of each factor and the mean value of the four tests; K3 represents the average value of the third level four tests of each factor; K4 represents the fourth level of each factor and the average of the four trials. 


\begin{tabular}{|c|c|c|c|c|c|}
\hline \multirow[t]{3}{*}{ No. } & \multirow[t]{3}{*}{ Combination } & & & & \multirow{3}{*}{$\begin{array}{l}\text { Viable bacteria } \\
\text { counts } \\
\left(\times 10^{13} \mathrm{cfu} / \mathrm{g}\right)\end{array}$} \\
\hline & & \multicolumn{3}{|c|}{ Matrix percentage(\%) } & \\
\hline & & $\begin{array}{l}\text { Carbon } \\
\text { source }\end{array}$ & $\begin{array}{l}\text { Nitrogen } \\
\text { source }\end{array}$ & $\begin{array}{l}\text { Inorganic } \\
\text { salt }\end{array}$ & \\
\hline $\begin{array}{l}\text { Best } \\
\text { organization }\end{array}$ & & K2 & $\mathrm{K} 4$ & K3 & \\
\hline \multicolumn{6}{|c|}{$\begin{array}{l}\text { Note: } k 1 \text { represents the average value of the four tests at the first level of each factor; } K 2 \text { represents the } \\
\text { second level of each factor and the mean value of the four tests; } K 3 \text { represents the average value of the } \\
\text { third level four tests of each factor; } K 4 \text { represents the fourth level of each factor and the average of the } \\
\text { four trials. }\end{array}$} \\
\hline
\end{tabular}

Results of optimization of parameters mentioned in the Table 5 depicted that the number of visible bacteria of strain 3-5 was highest when corn starch : beef extract : magnesium sulfate $=1.5: 2.5: 1.5$, with $2.415 \times$ $10^{13} \mathrm{cfu} / \mathrm{g}$. In summary, corn starch with $1.5 \%$ carbon source, beef extract with $2.5 \%$ nitrogen source and magnesium sulfate with $1.5 \%$ inorganic salt were chosen as the optimum carbon, nitrogen and inorganic salt combination in solid matrix of $B$. amyloliquefaciens $3-5$.

\subsubsection{Optimization of fermentation conditions}

As we expected, when the inoculation amount was $6 \%$, the solid-solid addition amount was $36 \mathrm{~g} / \mathrm{L}$, the solid-water ratio was $1: 1$ and the temperature was $32^{\circ} \mathrm{C}$, the viable count of $B$. amyloliquefaciens $3-5$ was the largest, which was $4.545 \times 10^{13} \mathrm{cfu} / \mathrm{g}$, which was significantly higher than that of other combinations. The results showed that the optimum fermentation conditions for strain 3-5 were as follows : a $6 \%$ inoculation rate, a solid addition rate of $36 \mathrm{~g} / \mathrm{L}$, solid-liquid ratio of $1: 1$ and temperature of $32^{\circ} \mathrm{C}$ ( Table 6 ). 
Table 6

Optimization of fermentation conditions

\begin{tabular}{|c|c|c|c|c|c|c|}
\hline \multirow[t]{3}{*}{ No. } & \multirow[t]{3}{*}{ Combination } & & & & & \multirow{3}{*}{$\begin{array}{l}\begin{array}{l}\text { Viable } \\
\text { bacteria } \\
\text { counts }\end{array} \\
\left(\times 10^{13} \mathrm{cfu} / \mathrm{g}\right)\end{array}$} \\
\hline & & \multicolumn{4}{|c|}{ Levels of conditions } & \\
\hline & & $\begin{array}{l}\text { Inoculum } \\
\text { size(\%) }\end{array}$ & $\begin{array}{l}\text { Solid } \\
\text { addition(g) }\end{array}$ & $\begin{array}{l}\text { Material } \\
\text { water } \\
\text { ratio }\end{array}$ & $\begin{array}{l}\text { Fermentation } \\
\text { temperature }\left({ }^{\circ} \mathrm{C}\right)\end{array}$ & \\
\hline 1 & $\mathrm{I}_{1} \mathrm{~S}_{1} \mathrm{M}_{1} \mathrm{~F}_{1}$ & 6 & 5 & $1: 0.6$ & 24 & 1.330 \\
\hline 2 & $\mathrm{I}_{1} \mathrm{~S}_{2} \mathrm{M}_{2} \mathrm{~F}_{2}$ & 6 & 7 & $1: 0.8$ & 28 & 1.885 \\
\hline 3 & $\mathrm{I}_{1} \mathrm{~S}_{3} \mathrm{M}_{3} \mathrm{~F}_{3}$ & 6 & 9 & $1: 1.0$ & 32 & 4.545 \\
\hline 4 & $\mathrm{I}_{1} \mathrm{~S}_{4} \mathrm{M}_{4} \mathrm{~F}_{4}$ & 6 & 11 & 1:1.2 & 36 & 0.560 \\
\hline 5 & $\mathrm{I}_{1} \mathrm{~S}_{5} \mathrm{M}_{5} \mathrm{~F}_{5}$ & 6 & 13 & $1: 1.4$ & 40 & 1.055 \\
\hline 6 & $\mathrm{I}_{2} \mathrm{~S}_{1} \mathrm{M}_{2} \mathrm{~F}_{3}$ & 8 & 5 & $1: 0.8$ & 32 & 4.433 \\
\hline 7 & $\mathrm{I}_{2} \mathrm{~S}_{2} \mathrm{M}_{3} \mathrm{~F}_{4}$ & 8 & 7 & $1: 1.0$ & 36 & 0.760 \\
\hline 8 & $\mathrm{I}_{2} \mathrm{~S}_{3} \mathrm{M}_{4} \mathrm{~F}_{5}$ & 8 & 9 & $1: 1.2$ & 40 & 0.668 \\
\hline 9 & $\mathrm{I}_{2} \mathrm{~S}_{4} \mathrm{M}_{5} \mathrm{~F}_{1}$ & 8 & 11 & $1: 1.4$ & 24 & 1.237 \\
\hline 10 & $\mathrm{I}_{2} \mathrm{~S}_{5} \mathrm{M}_{1} \mathrm{~F}_{2}$ & 8 & 13 & 1:0.6 & 28 & 0.175 \\
\hline 11 & $\mathrm{I}_{3} \mathrm{~S}_{1} \mathrm{M}_{3} \mathrm{~F}_{5}$ & 10 & 5 & 1:1.0 & 40 & 1.100 \\
\hline 12 & $\mathrm{I}_{3} \mathrm{~S} 2 \mathrm{M} 4 \mathrm{~F}$ & 10 & 7 & 1:1.2 & 24 & 0.933 \\
\hline 13 & $\mathrm{I}_{3} \mathrm{~S}_{3} \mathrm{M}_{5} \mathrm{~F}_{2}$ & 10 & 9 & $1: 1.4$ & 28 & 0.453 \\
\hline 14 & $\mathrm{I}_{3} \mathrm{~S}_{4} \mathrm{M}_{1} \mathrm{~F}_{3}$ & 10 & 11 & $1: 0.6$ & 32 & 0.078 \\
\hline 15 & $\mathrm{I}_{3} \mathrm{~S}_{5} \mathrm{M}_{2} \mathrm{~F}_{4}$ & 10 & 13 & $1: 0.8$ & 36 & 0.172 \\
\hline 16 & $\mathrm{I}_{4} \mathrm{~S}_{1} \mathrm{M}_{4} \mathrm{~F}_{2}$ & 12 & 5 & $1: 1.2$ & 28 & 0.702 \\
\hline 17 & $\mathrm{I}_{4} \mathrm{~S}_{2} \mathrm{M}_{5} \mathrm{~F}_{3}$ & 12 & 7 & $1: 1.4$ & 32 & 0.698 \\
\hline 18 & $\mathrm{I}_{4} \mathrm{~S}_{3} \mathrm{M}_{1} \mathrm{~F}_{4}$ & 12 & 9 & $1: 0.6$ & 36 & 0.270 \\
\hline
\end{tabular}

Note: $\mathrm{k} 1$ represents the first level of each factor and the mean value of the five tests; $\mathrm{K} 2$ represents the second level of each factor and the mean value of the five trials; K3 represents the third level of each factor and the average value of the five trials; K4 represents the fourth level of each factor and the average value of the five trials; K5 represents the fifth level of each factor and the average of the five trials. 


\begin{tabular}{|c|c|c|c|c|c|c|}
\hline \multirow[t]{3}{*}{ No. } & \multirow[t]{3}{*}{ Combination } & & & & & \multirow{3}{*}{$\begin{array}{l}\text { Viable } \\
\text { bacteria } \\
\text { counts } \\
\left(\times 10^{13} \mathrm{cfu} / \mathrm{g}\right)\end{array}$} \\
\hline & & \multicolumn{4}{|c|}{ Levels of conditions } & \\
\hline & & $\begin{array}{l}\text { Inoculum } \\
\text { size(\%) }\end{array}$ & $\begin{array}{l}\text { Solid } \\
\text { addition(g) }\end{array}$ & $\begin{array}{l}\text { Material } \\
\text { water } \\
\text { ratio }\end{array}$ & $\begin{array}{l}\text { Fermentation } \\
\text { temperature }\left({ }^{\circ} \mathrm{C}\right)\end{array}$ & \\
\hline 19 & $\mathrm{I}_{4} \mathrm{~S}_{4} \mathrm{M}_{2} \mathrm{~F}_{5}$ & 12 & 11 & $1: 0.8$ & 40 & 2.913 \\
\hline 20 & $\mathrm{I}_{4} \mathrm{~S}_{5} \mathrm{M}_{3} \mathrm{~F}_{1}$ & 12 & 13 & $1: 1.0$ & 24 & 2.737 \\
\hline 21 & $\mathrm{I}_{5} \mathrm{~S}_{1} \mathrm{M}_{5} \mathrm{~F}_{4}$ & 14 & 5 & $1: 1.4$ & 36 & 0.248 \\
\hline 22 & $\mathrm{I}_{5} \mathrm{~S}_{2} \mathrm{M}_{1} \mathrm{~F}_{5}$ & 14 & 7 & $1: 0.6$ & 40 & 0.328 \\
\hline 23 & $\mathrm{I}_{5} \mathrm{~S}_{3} \mathrm{M}_{2} \mathrm{~F}_{1}$ & 14 & 9 & $1: 0.8$ & 24 & 2.567 \\
\hline 24 & $\mathrm{I}_{5} \mathrm{~S}_{4} \mathrm{M}_{3} \mathrm{~F}_{2}$ & 14 & 11 & $1: 1.0$ & 28 & 3.140 \\
\hline 25 & $\mathrm{I}_{5} \mathrm{~S}_{5} \mathrm{M}_{4} \mathrm{~F}_{3}$ & 14 & 13 & $1: 1.2$ & 32 & 0.485 \\
\hline K1 & & 1.878 & 1.543 & 0.437 & 1.760 & \\
\hline K2 & & 1.435 & 0.924 & 2.377 & 1.274 & \\
\hline K3 & & 0.912 & 1.701 & 2.456 & 2.028 & \\
\hline K4 & & 1.463 & 1.586 & 0.670 & 0.403 & \\
\hline K5 & & 1.354 & 0.826 & 0.739 & 1.214 & \\
\hline $\begin{array}{l}\text { Best } \\
\text { organization }\end{array}$ & & K1 & K3 & K3 & K3 & \\
\hline $\begin{array}{l}\text { Note: k1 repr } \\
\text { second level } \\
\text { factor and th } \\
\text { average valu } \\
\text { trials. }\end{array}$ & $\begin{array}{l}\text { ts the first le } \\
\text { ach factor an } \\
\text { erage value o } \\
\text { the five trials }\end{array}$ & $\begin{array}{l}\text { of each } f \\
\text { he mean } \\
\text { he five tric } \\
5 \text { represer }\end{array}$ & $\begin{array}{l}\text { or and the } \\
\text { ue of the fi } \\
\text { K4 represe } \\
\text { the fifth lev }\end{array}$ & $\begin{array}{l}\text { In value } \\
\text { ials; K3 } \\
\text { the four } \\
f \text { each } f\end{array}$ & $\begin{array}{l}\text { he five tests; K2 r } \\
\text { esents the third le } \\
\text { evel of each facto } \\
\text { or and the averag }\end{array}$ & $\begin{array}{l}\text { oresents the } \\
\text { el of each } \\
\text { and the } \\
\text { of the five }\end{array}$ \\
\hline
\end{tabular}

\subsubsection{Optimization of initial pH of fermentation}

The $\mathrm{pH}$ value was an essential parameter to ensure the normal reproduction and metabolism of microorganisms, having great influence on fermentation. As shown in the Fig. 5 , the number of viable cells of strain 3-5 increased with the initial $\mathrm{pH}$ of fermentation. When the $\mathrm{pH}$ value was 4.5 , the viable count grew to reach a stable phase and the viable count grew at a faster speed when the $\mathrm{pH}$ value was 6; the number of viable cells, reached a maximum of $4.568 \times 10^{13} \mathrm{cfu} / \mathrm{g}$, was significantly higher than that at other $\mathrm{pH}$ values when the initial $\mathrm{pH}$ of fermentation was 7 . When the $\mathrm{pH}$ value was between 7.5 and 10 , the number of viable count was obviously decreased. Therefor, the initial $\mathrm{pH}$ value of fermentation was 7 , which was the optimal initial $\mathrm{pH}$ of the strain. 


\subsubsection{Optimization of fermentation time}

The fermentation time also was one of the key of parameters. As shown in the Fig. 6 , the number of viable cells of strain 3-5 changed as fermentation time increased. The number of viable bacteria was approach 0 when the fermentation time was less than $36 \mathrm{~h}$. When the fermentation time was $40 \mathrm{~h}$, the viable count was dramatic increase. Until the fermentation time was $44 \mathrm{~h}$, the number of viable bacteria was $2.835 \times 10^{12} \mathrm{cfu}$ $/ \mathrm{g}$, which was significantly higher than that of other fermentation times, and then significantly decreased. Obviously, $44 \mathrm{~h}$ was the strain's best fermentation time.

\subsection{Determination of the growth promoting effect of $B$. amyloliquefaciens 3-5 on cucumber}

The results of the pot control showed that the growth of cucumber plants after inoculation with different concentrations of biocontrol bacteria 3-5 differed significantly from the control. Cucumber plant height and underground dry weight were significantly higher than those of the control $(P<0.05)$ when the dosage of the microbial agent was $5 \% \sim 10 \%$, and the maximum plant height and underground dry weight were 26.05 $\mathrm{cm}$ and $0.22 \mathrm{~g}$ when the dosage of the microbial agent was $10 \%$. When the dosage of the microbial agent was $10 \%$, the root length was $23.58 \mathrm{~cm}$, which was significantly higher than other treatments and control groups. When the dosage of the microbial agent was $0.25 \%-20 \%$, the aboveground fresh weight and stem diameter of the plant were better than those of the control group, and the data showed that the aboveground fresh weight and stem diameter of the plant increased with dosage. When the dosage of the microbial agent was $10 \%$, the growth promotion effect was significant, and the aboveground fresh weight of the plant was $3.55 \mathrm{~g}$, with $0.23 \mathrm{~cm}$ thick stems (Table 7).

Table 7

Effect of 3-5 on the growth of cucumber plants

\begin{tabular}{|c|c|c|c|c|c|c|c|}
\hline \multirow{2}{*}{$\begin{array}{l}\text { Growth } \\
\text { parameter }\end{array}$} & \multicolumn{6}{|c|}{ Inoculant dosage } & \multirow[t]{2}{*}{ CK } \\
\hline & $0.25 \%$ & $0.5 \%$ & $1 \%$ & $5 \%$ & $10 \%$ & $20 \%$ & \\
\hline $\begin{array}{l}\text { Plant fresh } \\
\text { weight }(\mathrm{g})\end{array}$ & $\begin{array}{l}1.41 \pm \\
0.053 \mathrm{c}\end{array}$ & $\begin{array}{l}1.32 \pm \\
0.078 \mathrm{c}\end{array}$ & $\begin{array}{l}1.63 \pm \\
0.105 \mathrm{c}\end{array}$ & $\begin{array}{l}2.41 \pm \\
0.086 \mathrm{~b}\end{array}$ & $\begin{array}{l}3.55 \pm \\
0.5911 a\end{array}$ & $\begin{array}{l}2.70 \pm \\
0.226 \mathrm{~b}\end{array}$ & $\begin{array}{l}1.13 \pm \\
0.082 \mathrm{c}\end{array}$ \\
\hline $\begin{array}{l}\text { Plant dry } \\
\text { weight (g) }\end{array}$ & $\begin{array}{l}0.12 \pm \\
0.006 \mathrm{~b}\end{array}$ & $\begin{array}{l}0.10 \pm \\
0.010 \mathrm{~b}\end{array}$ & $\begin{array}{l}0.13 \pm \\
0.009 \mathrm{~b}\end{array}$ & $\begin{array}{l}0.16 \pm \\
0.010 \mathrm{~b}\end{array}$ & $\begin{array}{l}0.22 \pm \\
0.047 a\end{array}$ & $\begin{array}{l}0.15 \pm \\
0.008 \mathrm{~b}\end{array}$ & $\begin{array}{l}0.13 \pm \\
0.010 \mathrm{~b}\end{array}$ \\
\hline $\begin{array}{l}\text { Thick stems } \\
\text { (cm) }\end{array}$ & $\begin{array}{l}0.16 \pm \\
0.020 \mathrm{bc}\end{array}$ & $\begin{array}{l}0.19 \pm \\
0.015 \mathrm{abc}\end{array}$ & $\begin{array}{l}0.20 \pm \\
0.002 \mathrm{ab}\end{array}$ & $\begin{array}{l}0.21 \pm \\
0.024 \mathrm{ab}\end{array}$ & $\begin{array}{l}0.23 \pm \\
0.017 a\end{array}$ & $\begin{array}{l}0.18 \pm \\
0.019 a b c\end{array}$ & $\begin{array}{l}0.14 \pm \\
0.021 \mathrm{c}\end{array}$ \\
\hline $\begin{array}{l}\text { Root } \\
\text { length(cm) }\end{array}$ & $\begin{array}{l}18.10 \pm \\
1.320 a b\end{array}$ & $\begin{array}{l}13.12 \pm \\
0.875 b\end{array}$ & $\begin{array}{l}16.78 \pm \\
0.650 \mathrm{ab}\end{array}$ & $\begin{array}{l}18.77 \pm \\
1.285 a b\end{array}$ & $\begin{array}{l}23.58 \pm \\
5.128 a\end{array}$ & $\begin{array}{l}18.45 \pm \\
0.801 \mathrm{ab}\end{array}$ & $\begin{array}{l}16.79 \pm \\
0.650 \mathrm{ab}\end{array}$ \\
\hline $\begin{array}{l}\text { Plant height } \\
\text { (cm) }\end{array}$ & $\begin{array}{l}13.78 \pm \\
0.320 \mathrm{~cd}\end{array}$ & $\begin{array}{l}13.02 \pm \\
0.509 d\end{array}$ & $\begin{array}{l}15.38 \pm \\
0.614 c\end{array}$ & $\begin{array}{l}21.37 \pm \\
0.634 \mathrm{~b}\end{array}$ & $\begin{array}{l}26.05 \pm \\
1.045 a\end{array}$ & $\begin{array}{l}21.15 \pm \\
1.014 \mathrm{~b}\end{array}$ & $\begin{array}{l}13.20 \pm \\
0.442 d\end{array}$ \\
\hline
\end{tabular}




\subsection{Determination of the control effect of $B$. amyloliquefaciens $3-5$ on cucumber fusarium wilt}

The results of pot control showed that the disease index of prevention and treatment was significantly lower in the pot control group than in thecontrol group. The treatment effect was $48.83 \%$, and the prevention effect was $72.09 \%$. The prevention effect overperformed the treatment effect (Table 8).

Table 8

Control effect of 3-5 on cucumber Fusarium wilt in pot experiment

\begin{tabular}{|lll|}
\hline Treatment & Disease index /\% & Control effect $/ \%$ \\
\hline CK & 71.67 & - \\
\hline Preventive effect & 20.00 & 72.09 \\
\hline Therapeutic effect & 36.67 & 48.83 \\
\hline
\end{tabular}

\section{Discussion}

Modern chemical fungicides were less harmful than those of older generations, but agrochemicals in general still bring environmental harm such as health, environmental and ecological problems, severe toxicity, accumulation in the food chain and long degradation times (Vandenberghe et al. 2021). Thus, the development of environmentally friendly alternatives has been encouraged over the years. Bioproducts with low environmental impact and multiple mechanisms of action have emerged, and they can be of plant origin such as essential oils which have shown antifungal activities, among others (Vandenberghe et al. 2021), or they can be antagonistic living organisms (Leiter et al. 2017) as well as their natural metabolites. These bioproducts with antifungal activities are called biofungicides, and they can be produced in several ways.

Solid-state fermentation (SSF) has enormous potential because of its lower production investment, shorter fermentation time and higher yield of secondary metabolites (Vandenberghe et al. 2021). It was eported that the differences in physiological changes mediated by submerged fermentation (SmF) and SSF can cause differences in microbial molecular behavior that affect product formation and yield (Barrios-González et al. 2008). Compared to SmF, SSF offers the advantages of lower energy consumption, lower cost, and simpler techniques (Zhang et al. 2014 ). Whatever the fermentation technique, high spore yields were often achieved based on careful experimental designs for industrial exploitation. A considerable increase in the production of alpha-amylase by $B$. amyloliquefaciens in flask fermentation using statistical methods was reported by Zhao et al. (2011). The substrate used in the present study, i.e. wheat bran, was reported to be potent substrate for the production of alpha-amylase under SSF (Ramachandran et al. 2004). Therefore, the development of low-cost and highly efficient technologies for the production of spore-forming probiotics became necessary. It was generally accepted that SSF has several biotechnological advantages; it was a simple and low-investment process as it requireed low energy consumption, cheap plant raw materials can be used as growth substrates, and after SSF, the product can be lyophilized directly without centrifugation. 
It also provides higher productivity of fermentation and higher concentration of products (Holker et al. 2004).

The development of efficient technologies for the production of spore-forming bacteria requires understanding of the physiological mechanisms that regulate Bacilli growth and sporulation, as well as elucidation of the conditions that favor both processes. Sporulation of Bacillus spp. depends on medium composition, pH, aeration, temperature, and other factors (Ren et al. 2018; Posada-Uribe et al. 2015). Limited information is available in the literature on the effect of lignocellulosic substrates on sporulation of bacilli. Among the four growth substrates tested for submerged fermentation of Bacillus spp. KKU02 and KKU03, cassava root supported sporulation better than basal nutrient broth (Wangka-Orm et al. 2014). These strains formed $8.32 \times 10^{8}$ spores $\mathrm{ml}^{-1}$ and $1.35 \times 10^{8}$ spores $\mathrm{ml}^{-1}$, respectively, of an optimal cassava concentration of $100 \mathrm{~g} \mathrm{~L}^{-1}$. A combination of tapioca with lactose in a nutrient medium for submerged cultivation of $B$. amyloliquefaciens subsp. B128 resulted in a spore yield of $5.92 \times 10^{8}$ spores $\mathrm{ml}^{-1}$ (Posada-Uribe et al. 2015). The reasonable way to increase spore production is to create optimal cultivation conditions that promote maximum vegetative cell accumulation followed by effective sporulation. One of the valid approaches is to supplement the culture medium with a suitable nitrogen source at the optimal concentration. To achieve this goal, several abundantly available agro-industrial byproducts were tested. Among these growth substrates, bran followed by rice bran and corn straw, provided particularly high yields of spores. These results suggest that a distinctive feature of $B$. amyloliquefaciens $3-$ 5 is its ability to use various low-cost lignocellulosic materials as growth substrates for high-yield spore production. Similar results were reported for submerged cultivation of $B$. subtilis where ammonium sulfate $(4.54 \%)$ in combination with corn flour (1.2\%) resulted in maximum spore production (Khardziani et al. 2017). Furthermore, using a response surface method, Rao et al. (2007) optimized the composition of the medium for maximum spore production of $B$. amyloliquefaciens subsp. B128 and showed that a mixture of $\left(\mathrm{NH}_{4}\right)_{2} \mathrm{SO}_{4}$ and peptone gave the highest yield of spores at concentrations of 1.8 and $8.0 \mathrm{~g} \mathrm{~L}^{-1}$, respectively. In this study, we attempted to reduce the cost of probiotics production by using low cost raw materials as medium components by optimizing of the medium for significant increase in spore yield.

Recently, several studies have investigated the antagonistic activity of different bacterial strains on phytopathogenic fungi in postharvest fruits, so their use can be considered as an alternative in controlling fungal diseases by chemical methods (Ma et al. 2019). B. amyloliquefaciens 3-5 as an endophytic bacterium with good biocontrol potential. In this study, its fixed fermentation conditions were optimized. The results showed that wheat bran was the carrier, corn flour was the carbon source and soybean meal was the nitrogen source. $35 \%$ bran, $40 \%$ rice husk meal, $20 \%$ corn meal and $15 \%$ soybean meal were selected as the composite matrix for solid-state fermentation of strain 3-5. The best carbon source was $1.5 \%$ corn starch, $2.5 \%$ beef paste and $1.5 \%$ magnesium sulfate. The optimal fermentation conditions were $6 \%$ inoculation, $36 \mathrm{~g} / \mathrm{L}$ solid addition, $1: 1$ ratio of material to water, $32^{\circ} \mathrm{C}$ temperature, $\mathrm{pH} 7$ and $44 \mathrm{~h}$ fermentation time. The results of this study provided the basis for the production of the bactericide of $B$. amyloliquefaciens 3-5, and also provided the Micrabiae resources for the biological control of cucumber Fusarium wilt. 
It is widely known that Fusarium wilt, as a destructive and economic disease, is very difficult to control by classical methods because there is no effective chemical treatments. In addition, it is not practical to control the soil-borne diseases with chemicals, biological control is a realistic approach for the management of Fusarium wilt. For all these reasons, there is an urgent need for plant disease control in agriculture.

In this research, $B$. amyloliquefaciens 3-5 showed that preventive effect on cucumber Fusarium wilt and therapeutic effect was $72.09 \%$ and $48.83 \%$ by applying $B$. amyloliquefaciens $3-5$ agent by pot culture experiments under greenhouse conditions. $B$. amyloliquefaciens 3-5 agent developed in this laboratory significantly reduced the incidence and severity index of cucumber Fusarium wilt and can partially reduce the economic losses. Thus, $B$. amyloliquefaciens 3-5 agent can effectively control cucumber Fusarium wilt. Biocontrol agents developed by antagonistic strains do not pollute the environment, which is beneficial for maintaining the balance of the ecosystem and promoting agriculture. At present, this experiment only studied the development of $B$. amyloliquefaciens 3-5 indoor research for disease prevention, growth promotion. However, the application of $B$. amyloliquefaciens 3-5 agent in the field needs further investigation.

\section{Abbreviations}

FOC: Fusarium oxysporum f. sp. cucumerinum

DI: Disease incidence

SD: Standard deviation

SSF: Solid-state fermentation

SmF: Liquid fermentation

\section{Declarations}

\section{Ethics Approval and Consent to Participate}

Not applied.

\section{Consent for Publication}

Not applied.

\section{Availability of Data and Materials}

Data and materials available on request from the authors. The data and materials that support the findings of this study are available from the corresponding author upon reasonable request.

\section{Competing Interests}


All authors declare that there is no conflict of competing interests in this original article.

\section{Funding}

This work was supported by the project of National Natural Science Foundation of China (No: 31660148) and by the Science and Technology Innovation Fund of Gansu Agricultural University (No:GAU-XKJS-2018148).

\section{Authors' Contributions}

All authors contributed to the study conception and design. Ting Ma conceived and designed reseach. Chengde Yang wrote the reviews. Ting Ma and Fengfeng Cai conducted experiments. Lingxiao Cui contributed new reagents. Ting Ma and Yidan Wang analyzed data. Ting Ma wrote the manuscript. All authors read and approved the manuscript.

\section{Acknowlegements}

Thanks to everyone who contributed to this article, including corresponding authors, co-authors, and others.

\section{Author Information}

\section{Affiliations}

College of Plant Protection, Biocontrol Engineering Laboratory of Crop Diseases and Pests of Gansu Province, Gansu Agricultural University, Lanzhou, 730070, China

Ting Ma, Chengde Yang*, Fengfeng Cai, Lingxiao Cui, Zhezhe Li, Yidan Wang

\section{Corresponding author}

Correspondence to yangcd@gsau.edu.cn.

\section{References}

1. Asaka O, Shoda M (1996). Biocontrol of Rhizoctonia solani damping-off of tomato with Bacillus subtilis RB14. Appl Environ Microbiol 62:4081-4085.

2. Bargabus, R. L., Zidack, N. K., Sherwood, J. E., \& Jacobsen, B. J (2002). Characterization of systemic resistance in sugar beet elicited by a nonpathogenic, phyllosphere-colonizing Bacillus mycoides, biological control agent. Physiological and Molecular Plant Pathology 61, 289-298.

3. Bakker, P. A. H. M., Pierterse, C. M. J., \& Van Loon, L. C (2007). Induced systemic resistance by fluorescent Pseudomonas spp. Phytopathology 97, 239-243.

4. Barrios-González J, Baños JG, Covarrubias AA, Garay-Arroyo A (2008). Lovastatin biosynthetic genes of Aspergillus terreus are expressed differentially in solid-state and in liquid submerged fermentation. Appl Microbiol Biotechnol 79:179-186. 
5. Compant S, Duffy B, Nowak J, Clément C, Barka EA (2005). Use of plant growth-promoting bacteria for biocontrol of plant diseases: principles, mechanisms of action, and future prospects. Appl Environ Microbiol 71:4951-4959.

6. Cao Y, Zhang Z, Ling N, Yuan Y-J, Zheng X, Shen B, Shen Q-R (2011). Bacillus subtilis SQR 9 can control Fusarium wilt in cucumber by colonizing plant roots. Biol Fertil Soils 47:495-506.

7. Cha J-Y, Han S, Hong H-J, Cho HJ, Kim D, Kwon Y, Kwon SK, Crüsemann M, Lee YB, Kim JF, Giaever G, Nislow C, Moore BS, Thomashow LS, Weller DM, Kwak YS (2016). Microbial and biochemical basis of a Fusarium wilt-suppressive soil. IsmeJ 10:119.

8. El Komy MH, Saleh AA, Eranthodi A, Molan YY (2015). Characterization of novel Trichoderma asperellum isolates to select effective biocontrol agents against tomato Fusarium wilt. Plant Pathol $\mathrm{J}$ 31(1):50-60.

9. Feng, X., Li, SP., Lu, YF. et al (2021). Bjerkandera adusta M1 inhibits the growth of Fusarium oxysporum f. sp. conglutinans and fusarium wilt incidence in Brassica napus L.. J Plant Pathol 103, 483-491.

10. Haas D, Keel C (2003). Regulation of antibiotic production in rootcolonizing Peudomonas spp. and relevance for biological control of plant disease. Annu Rev Phytopathol 41:117-153.

11. Holker U, Hofer M, Lenz J (2004). Biotechnological advantages of laboratory scale solid-state fermentation with fungi. Appl Microbiol Biotechnol 64(2):175-186.

12. Haas D, Défago G (2005). Biological control of soil-borne pathogens by fluorescent Pseudomonads. Nat Rev Microbiol 3:307-319.

13. Janga MR, Raoof MA, Ulaganathan K (2017). Effective biocontrol of Fusarium wilt in castor (Ricinius communis L.) with Bacillus sp. in pot experiments. Rhizosphere 3:50-2.

14. Kloepper, J. W., Ryu, C. M., \& Zhang, S (2004). Induced systemic resistance and promotion of plant growth by Bacillus spp. Phytopathology 94, 1259-1266.

15. Kang, S. H., Cho, H. S., Cheong, H., Ryu, C. M., Kim, J. F., \& Park, S. H (2007). Two bacterial endophytes eliciting boot plant growth promotion and plant defense on pepper (Capsicum annuum L.). Journal of Microbiology and Biotechnology 17, 96-103.

16. Khardziani T, Kachlishvili E, Sokhadze K, Elisashvili V, Weeks R, Chikindas ML, Chistyakov V (2017). Elucidation of Bacillus subtilis KATMIRA 1933 potential for spore production in submerged fermentation of plant raw materials. Probiotics Antimicro Prot 9(4):435-443.

17. Kubiak M, Borkowska M, Bialas W, Korpys P, Celinska E (2019). Feeding strategy impacts heterologous protein production in Yarrowia lipolytica fed-batch cultures-insight into the role of osmolarity. Yeast 36:305-318.

18. Lugtenberg B, Kamilova F (2009). Plant-growth-promoting rhizobacteria. Anu Rev Microbiol 63:541556.

19. Li, CH., Zhao, MW., Tang, CM. et al (2010). Population Dynamics and Identification of Endophytic Bacteria Antagonistic Toward Plant-Pathogenic Fungi in Cotton Root. Microb Ecol 59, 344-356.

20. Leiter É, Gáll T, Csernoch L, Pócsi I (2017). Biofungicide utilizations of antifungal proteins of filamentous ascomycetes: current and foreseeable future developments. Biocontrol 62:125-38. 
21. Mishra, R. P., Singh, R. K., Jaiswal, H. K., Kumar, V., \& Maurya, S (2006). Rhizobium mediated induction of phenolics and plant growth promotion in rice (Oryza sativa L.). Current Microbiology 52, 383-389.

22. Mizumoto S, Hirai M, Shoda M (2006). Production of lipopeptide antibiotic iturin A using soybean curd residue cultivated with Bacillus subtilis in solid-state fermentation. Appl Microbiol Biotechnol 72:869875.

23. Markakis EA, Tjamos SE, Antoniou PP, Paplomatas EJ, Tjamos EC (2016). Biological control of Verticillium wilt of olive by Paenibacillus alvei, strain K165. Biocontrol 61:293-303.

24. Ma J, Hong Y, Deng L et al (2019). Screening and characterization of lactic acid bacteria with antifungal activity against Penicillium digitatum on citrus. Biol Control 138:104044.

25. Posada-Uribe LF, Romero-Tabarez M, Villegas-Escobar V (2015). Effect of medium components and culture conditions in Bacillus subtilis EA-CB0575 spore production. Bioprocess Biosyst Eng 38(10):1879-1888.

26. Palazzini JM, Dunlap CA, Bowman MJ, Chulze SN (2016). Bacillus velezensis RC 218 as a biocontrol agent to reduce Fusarium head blight and deoxynivalenol accumulation: genome sequencing and secondary metabolite cluster profiles. Microbiol Res 192:30-6.

27. Pandey A (ed) Concise encyclopedia of bioresource technology. Haworth Press, New York, pp 702-718.

28. Park, Cj., Kim, Hs., Lee, D.W. et al (2020). Identification of antifungal constituents of essential oils extracted from Boesenbergia pulcherrima against Fusarium wilt (Fusarium oxysporum). Appl Biol Chem 63, 34.

29. Qiu M-H, Zhang R-F, Xue C, Zhang S-S, Li S-Q, Zhang N, Shen Q-R (2012). Application of bio-organic fertilizer can control Fusarium wilt of cucumber plants by regulating microbial community of rhizosphere soil. Biol Fertil Soils 48:807-16.

30. Ramachandran S, Patel AK, Nampoothiri KM, Francis F, Nagy V, Szakacs G, Soccol CR, Pandey A (2004). Coconut oil cake-a potential raw material for the production of alpha amylase. Bioresour Technol 93:169-174.

31. Rao YK, Tsay KJ, WS W, Tzeng YM (2007). Medium optimization of carbon and nitrogen sources for the production of spores from Bacillus amyloliquefaciens B128 using response surface methodology. Process Biochem 42(4):535-541.

32. Rashad YM, Al-Askar AA, Ghoneem KM, Saber WI, Hafez EE (2017). Chitinolytic Streptomyces griseorubens E44G enhances the biocontrol efficacy against Fusarium wilt disease of tomato. Phytoparasitica 45:227-37.

33. Ren H, Su YT, Guo XH (2018). Rapid optimization of spore production from Bacillus amyloliquefaciens in submerged cultures based on dipicolinic acid fluorimetry assay. AMB Express 8:21.

34. Senthilkumar, M., Govindasamy, V., \& Annapurna, K (2007). Role of antibiosis in suppressionof charcoal rot disease by soybean endophyte Paenibacillus sp. HKA-15. Current Microbiology 55, 25-29.

35. Sanogo, S., Zhang, J (2016). Resistance sources, resistance screening techniques and disease management for Fusarium wilt in cotton. Euphytica 207, 255-271. 
36. Turner JT, Backman PA (1991). Factors relating to peanut yield increases after seed treatment with Bacillus subtilis. Plant Dis 75:347-353.

37. Vandenberghe, L.P.S., Pandey, A., Carvalho, J.C. et al (2021). Solid-state fermentation technology and innovation for the production of agricultural and animal feed bioproducts. Syst Microbiol and Biomanuf 1, 142-165.

38. Wang, Y., Zhao, B., Liu, Y. et al (2020). A novel trehalosamine isolated from Bacillus amyloliquefaciens and its antibacterial activities. AMB Expr 10, 6.

39. Wangka-Orm C, Deeseenthum S, Leelavatcharamas V (2014). Low cost medium for spore production of Bacillus KKU02 and KKU03 and the effects of the produced spores on growth of giant freshwater prawn (Macrobrachium rosenbergii de Man). Pak J Biol Sci 17(8):1015-1022.

40. Wang K, Tian Y, Zhou N, Liu D, Zhang D (2018). Studies on fermentation optimization, stability and application of prolyl aminopeptidase from Bacillus subtilis. Process Biochem 74:10-20.

41. Zhao W, Zheng J, Wang YG, Zhou H (2011). A marked enhancement in production of amylase by Bacillus amyloliquefaciens in flask fermentation using statistical methods. J Cent South Univ Technol 18:1054-1062.

42. Zhang YR, Xiong HR, Guo XH (2014). Enhanced viability of Lactobacillus reuteri for probiotics production in mixed solid-state fermentation in the presence of Bacillus subtilis. Folia Microbiol 59:3136.

\section{Figures}




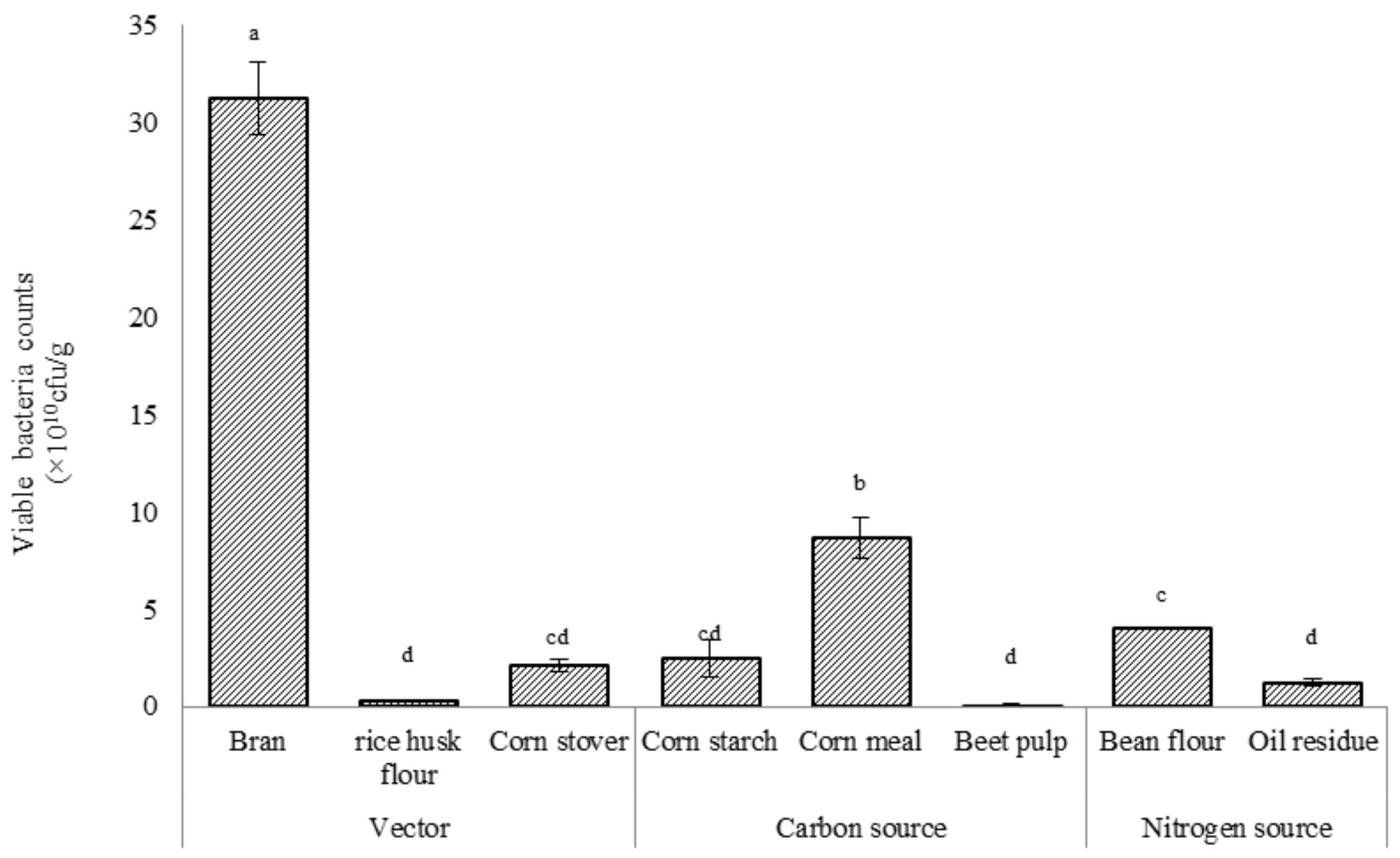

Figure 1

Single substrate screening for solid fermentation of strain 3-5 Note: Different lowercase letters in the fig mean significantly different at $\mathrm{p} \otimes 0.05$ level with Duncan's new multiple range least, the same below.

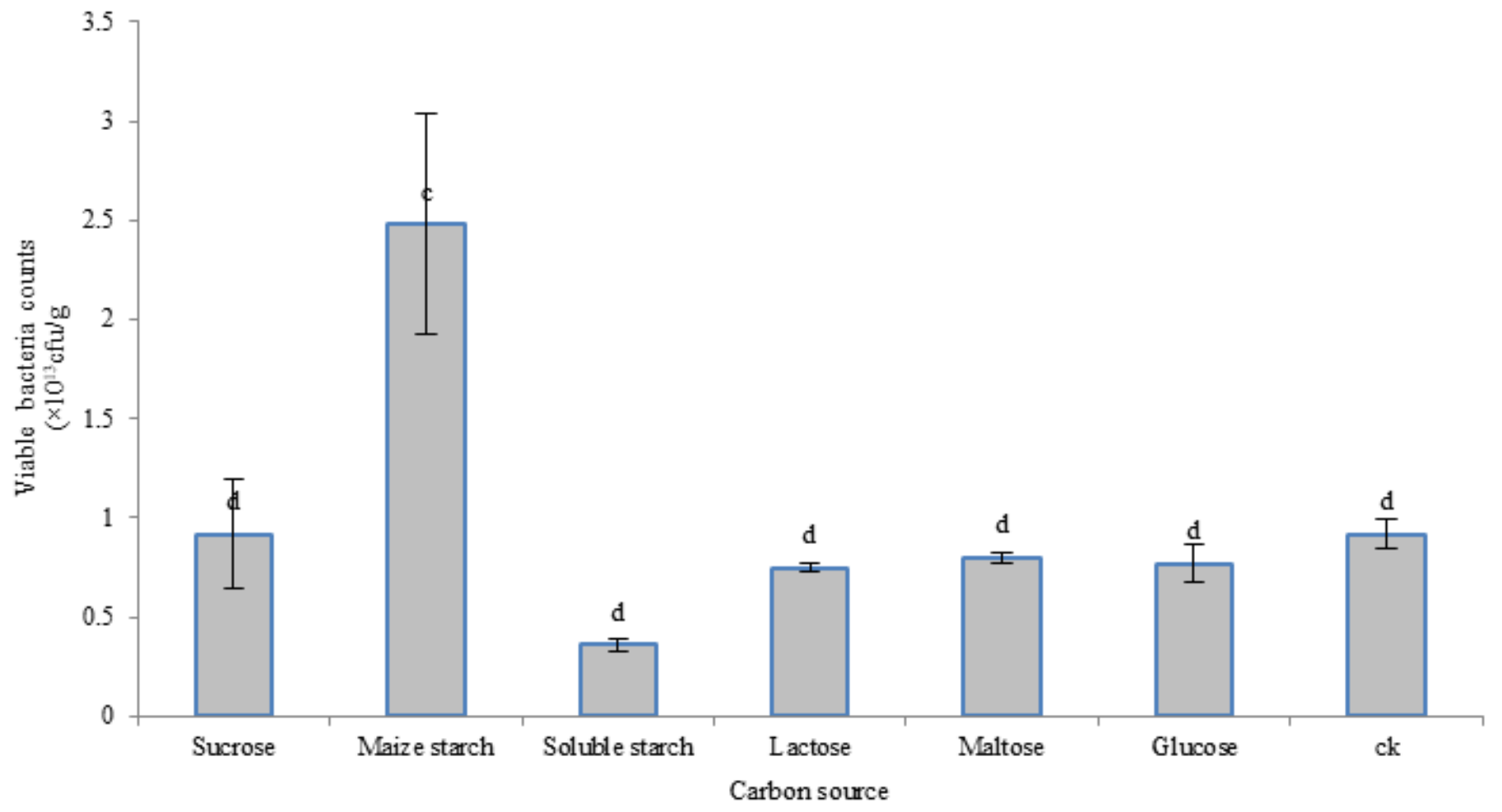


Figure 2

The effect of carbon source on the number of viable bacteria

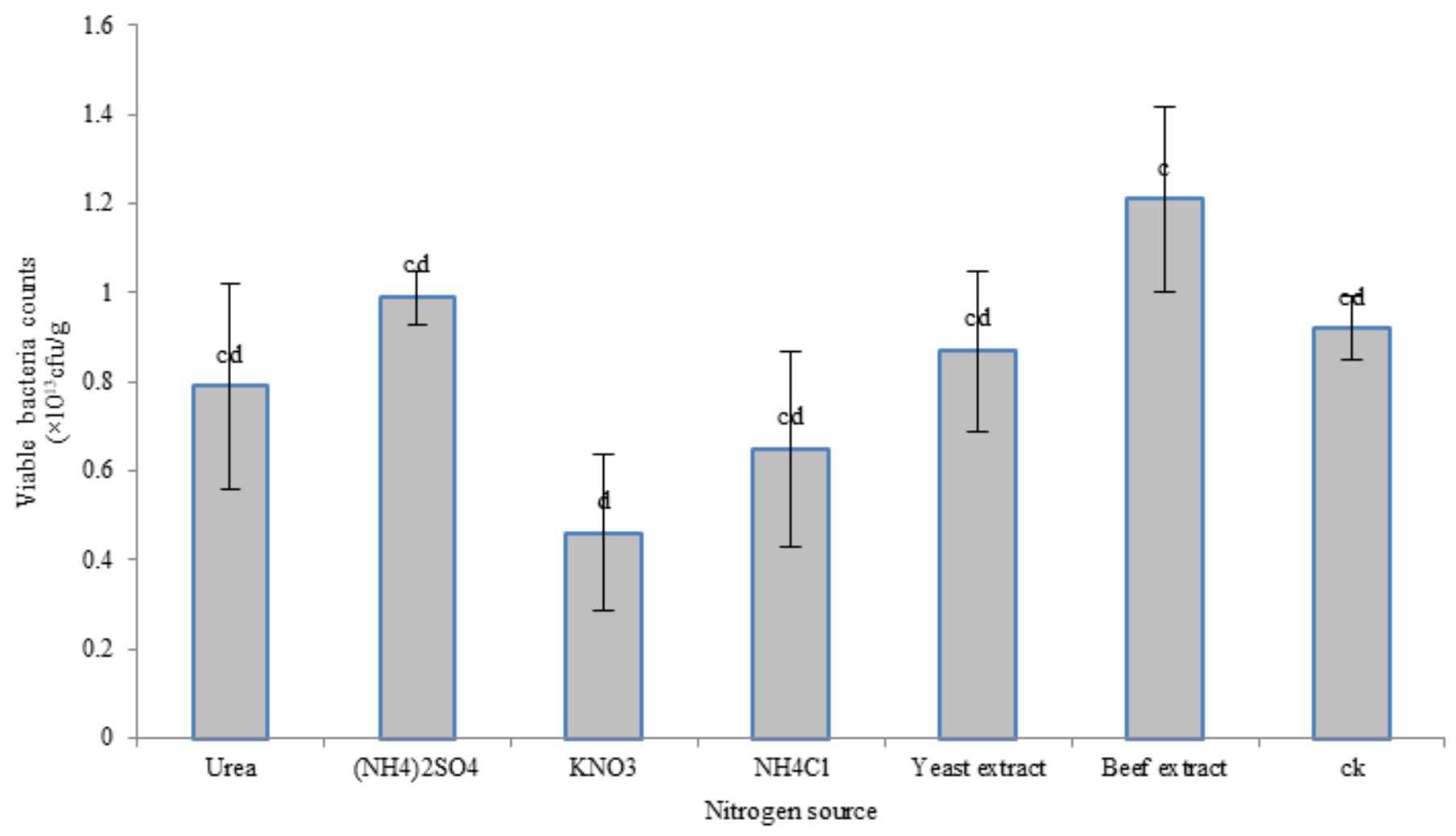

Figure 3

Effect of nitrogen source on the number of viable bacteria 


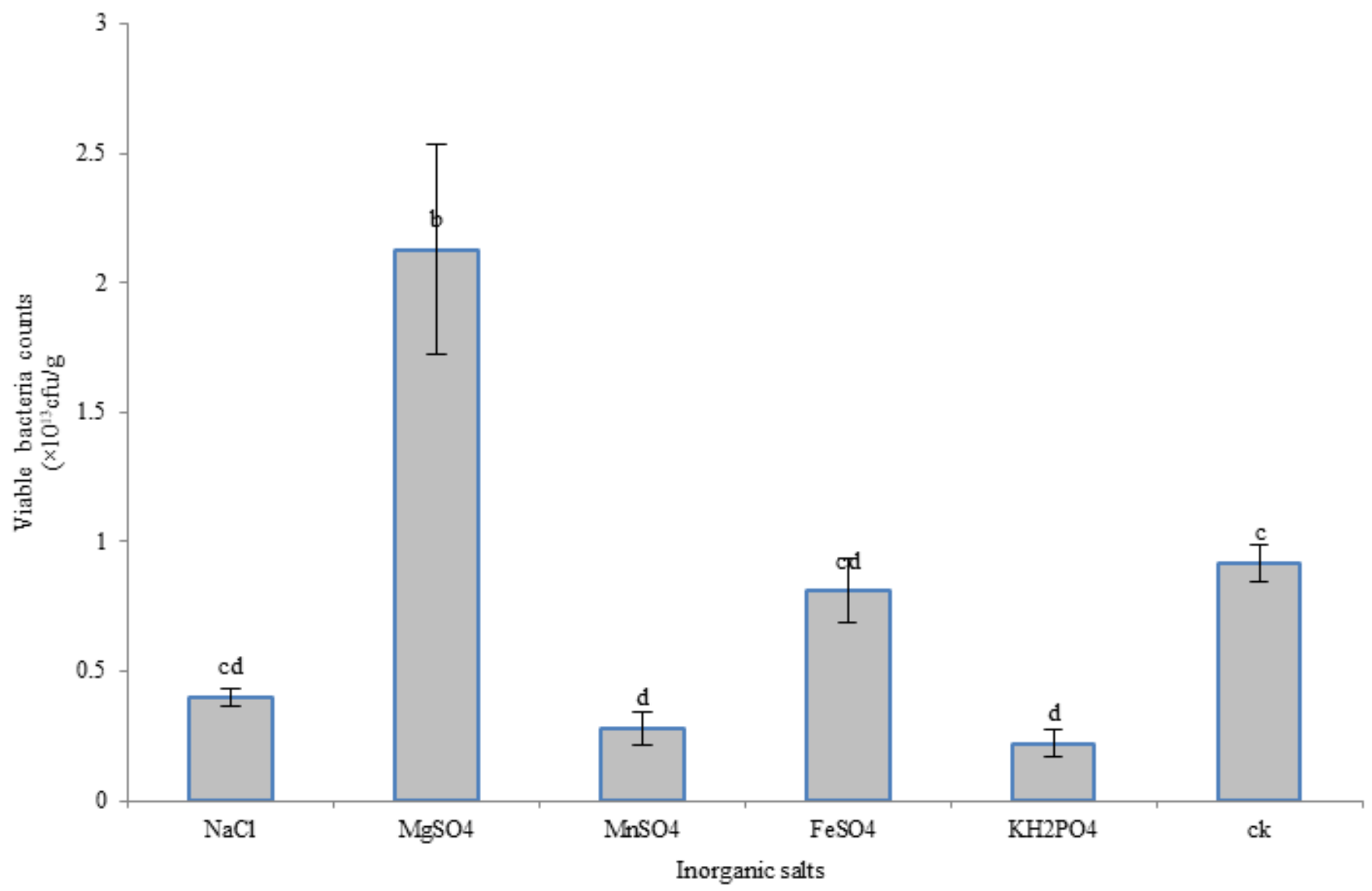

Figure 4

Effects of inorganic salts on the number of viable bacteria 


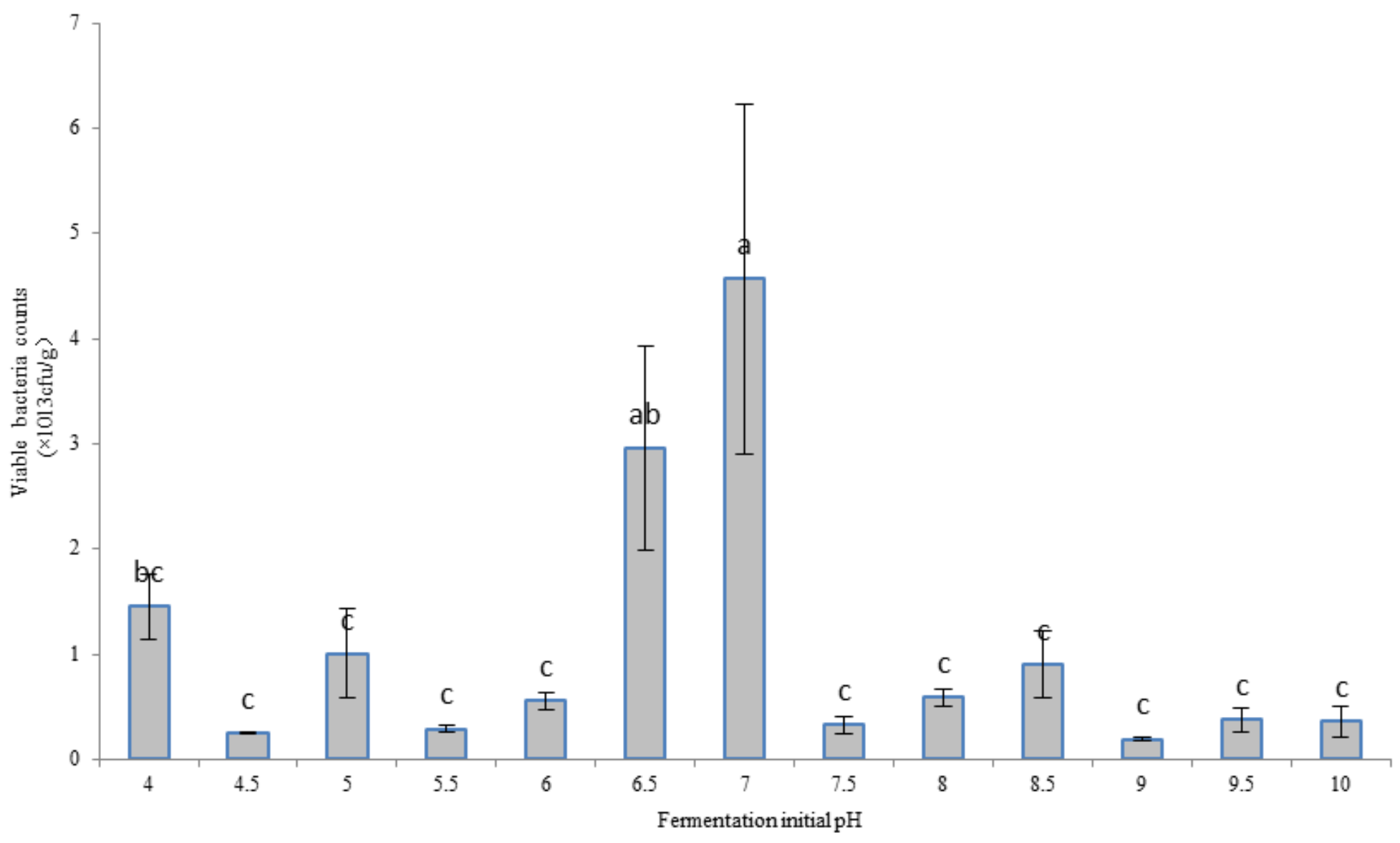

Figure 5

Effect of initial pH on the number of viable bacteria

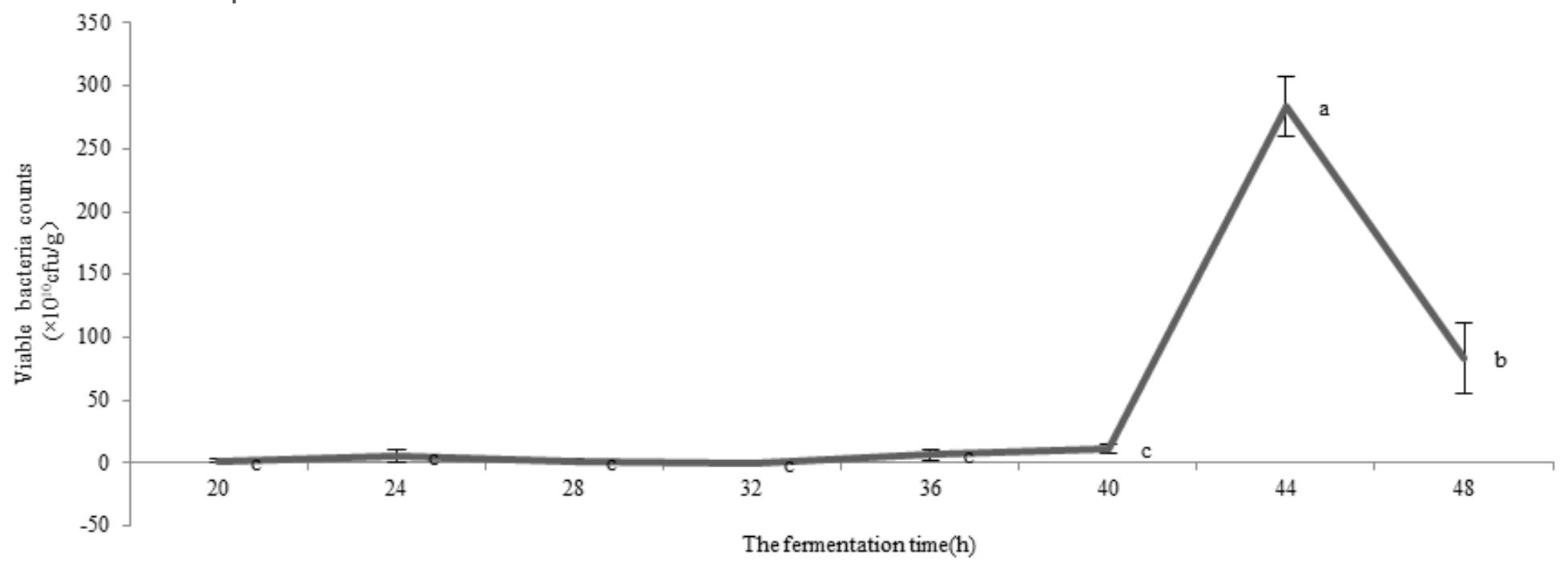

Figure 6

Effect of fermentation time on the number of viable bacteria 